\title{
Narratiiv kui ravi: riituse-etendus ja narratiivi aktualiseerumine kogemusena
}

Teesid: Artiklis tegeldakse narratiiviga seonduvate teoreetiliste küsimustega, et mõista teatud tervendamisriituste semantikat. Esimese osas kasutusele võetud termin narratiivne vägi viitab narratiivide kultuurilisele laetusele ja narratiivsetele strateegiatele ning käsitleb tervendamisriitust kui narratiivi aktualiseerimist kogemusena. Soome-Karjala tietäjä-traditsiooni vaadeldakse seostatuna šamanistliku riituse-etenduse ja päheõpitud loitsupärimusega, eriti nende loitsudega, milles sisalduvad ka historiolad. Võrdlev analüüs võimaldab täpsemalt uurida narratiivse väe rolli traditsiooni kujundamisel aja jooksul.

Märksõnad: etendus, loits, mitte-propositsionaalne tähendus, rituaal, šamaan, tervendamisriitus, tietäjä

\section{Sissejuhatus}

"Iga rituaal on meie kogemuse korduv, koherentselt struktureeritud ja unikaalne aspekt", mille kaudu me "anname struktuuri ja tähenduse oma tegevustele ning minimeerime kaost ja lahknevusi oma tegevuses" (Lakoff \& Johnson 1980: 234-235).

Käesolev artikkel pakub välja käsitluse, mõistmaks strateegiaid, mis kaasnevad teatud tüüpi maagiliste etendustega - semantika, miks või kuidas saaks neid mõista tõhusate strateegiatena. Käsitlen maagilist riituse läbiviimist kui narratiivi vormi. Riituse kulgu käsitletakse narratiivina, sest tegu on piiritletud järjestikuliste sündmustega, millel on algus, keskpaik ja lõpp, ning mille järjestikuline struktuur on esteetilises mõttes semiootiliselt markeeritud, võttes arvesse nende sõltumatute elementide väärtusi teistes kontekstides kasutamisel, ning ka selles mõttes, missugused elemendid on semiootiliselt olulised ning millised neist on esitamise ajal "nähtamatud". Riituse esitamist käsitletakse kui midagi, mis aktualiseerib riituse narratiivse kogemusena, mitte kui suhtlemise või meelelahutuse strateegiat ega kogemuse paigutamist "tähenduslikku, kohasesse vormi” (Hymes 1975: 346). 
Keskendun Soome-Karjala riituse-spetsialisti tietäjä tervendamisriitustele. ${ }^{1}$ Tietäjä tervendamisriitust on narratiivina käsitlenud ka Lauri Honko (1960; vrd Honko 1959: 202-207), kirjeldades seda kui teatud 'tervendamisdraama' vormi (sm parantamisnäytelmä, tervendamis-etendus), ${ }^{2}$ ja Ulla Piela (2005) oma hiljutises artiklis, kus ta käsitleb antud analoogiat. Tervendamisriituse analoogia 'tervendamisdraamaga' põhineb võrdlusel teiste põhjamaiste kultuuride šamaaniriitustega. Tietäja strateegiat võib kirjeldada subarktilise šamanismi ja Euroopa loitsimistraditsiooni järeltulijana (vt Siikala 1992; 2002a).

Artikkel on jaotatud viide ossa, alustatakse teooria üksikasjaliku käsitlusega, et tutvustada kontseptsioone. Termini narratiivne vägi abil antakse raamistik mõistmaks, kuidas kasutatakse narratiivseid strateegiaid tähenduslike kogemuste aktualiseerimiseks, või selleks, et aktualiseerida kogemusi, mida teised tajuvad tähenduslikena.

Teises osas käsitletakse seda nähtust šamaanlikes riituseetendustes, eriti narratiivsete strateegiate ilmnemist subjektiivsetes nägemuslikes kogemustes. Vastupidiselt šamaanile rakendab tietäja nähtamatu maailmaga suheldes esmase töövahendina loitsimist, mille puhul kasutatakse ohtralt narratiivset materjali, historiolasid. Kolmandas osas antakse ülevaade historioladest ja neljandas keskendutakse tietäja riituse laiematele strateegiatele, käsitledes neid kui esilekerkivaid narratiive, mis aktualiseerivad narratiivi kogemusena. Viiendas peatükis jälgitakse põgusalt, kuidas toimivad narratiivse väega seostatavad strateegiad pärimuse kujundamisel ja arengus.

\section{Narratiiv}

Mingit nimekirja kuulates me tegeleme sõna-sõnalt ja täht-tähelt nimekirjas olevate nimetustega; kuulates mingit [narratiivi] hakkame aru saama seostest nende nimetuste vahel (Ross 1975: 2).

Terminit narratiiv kasutatakse väga erinevas tähenduses ning konkreetset definitsiooni on raske ja problemaatiline välja pakkuda (vt nt Kaivola-Bregenhøj 1996:12-18). Ingliskeelne termin narrative esineb akadeemilistes uurimustes ka paljudes teistes keeltes (nt soomekeelne narratiivi). Eelkõige kasutatakse terminit verbaalse loomingu kohta, kuigi verbaalsus on ainult üks narratiivi aspektidest (vt Honko 2000: 3-15). Sõnaline väljendus ei ole narratiivses kommunikatsioonis (nt ikonograafilises representatsioonis) kõige olulisem, individuaalsed narratiivid võivad levida väga mitmekesistes väljendusvormides (näit Jeesuse elu ja surma puudutavad narratiivid). Selline dünaamilisus on oluline, tõmbamaks paralleele riituse etendamise ja 'draama' vahele ning käsitlemaks riituse läbiviimist kui narratiivi ja narratiivi kasutamist riituse läbiviimisel. 
Huvitaval kombel on ingliskeelne termin narrative vähem deskriptiivne kui see, mida ta kirjeldab või kuidas selle referenti (s.t narratiivi) käsitletakse: termin kätkeb endas objektiivsust, formaalsust, ta võib ka tegelda objektiga tehnilisel viisil.

\section{Narratiivi tunnused: sidususe ja semiootilisuse eeldus}

Kui me peaksime aktsepteerima argumente, mis rõhutavad [narratiivi puhul] lineaarse struktuuri olulisust, võiksime keelduda neid narratiivideks nimetamast, kuna nad on seosetud ja neid puudub järgnevus. [---] on selge, et inimesed [---] püüdsid valada sõnulseletamatuid kogemusi narratiivsesse vormi, et nad pü̈̈dsid rääkida lugusid. Samamoodi on selge, et nad olid teadlikud oma jõupingutuste piisamatusest. (Briggs 2003: 77, autori rõhuasetus.)

Aeg ja põhjuslikud seosed tunduvad narratiivi puhul olulised. Teisisõnu tegeleb narratiiv ajalise järjestatusega, ja järgnevus(t)e elemendid peegeldavad keerukat või ka ilmset lineaarset katkematust isegi siis, kui see lineaarne järjepidevus ei vasta esituse korraldusele (vrd Klein 2006: 14-15). Annikki KaivolaBregenhøj (1996: 191) tuletab meile meelde: "jutustaja mälust võetud narratiiv on alati mingist laiemast narratiivsest üksusest." See võib nii olla, sest 'narratiiv' on pelgalt üks kontiinumist ekstraheeritud segment, piiratud hulga elementide (detailide, motiivide, episoodide) valik ja korraldatus 'tervikust', ja ka "vahelduvad vaimsed tegevused, mis tagavad teksti alternatiivse ja tegeliku korrastatuse" (Tsur 1992a: 30) - s.t konkreetne artikulatsioon vastandatuna potentsiaalsele, kuid realiseerimata väljendustele. ${ }^{3}$ Seega ei sõltu identiteet kui 'narratiiv' produkti 'lõpetatusest'. Ka ei ole selline identiteet sõltuv produkti 'terviklikkusest': nii edukad ${ }^{4}$ kui ka ebaedukad ${ }^{5}$ esitused võivad üldistavast (ingl etic) seisukohast osutuda 'mittetäielikuks/lõpetamatuks'. Seetõttu võiks terminit 'narratiiv' kirjeldada kui suhet 'narratiivi' tulemuse ja selle laiema üksuse vahel, või kui narratiivse ideaali reflektsiooni või osalist representatsiooni - isegi kui see ideaal eksisteerib ainult esitaja vaimus. Ajalise järjekorra lagunemine ja/või nende suhted võivad mõjutada meie hinnangut tulemuse kvaliteedi, informandi pädevuse või mälu kohta, kuid see ei pea tingimata osundama, et vastav tulemus ei ole 'narratiiv'. Charles Briggs on rõhutanud, et järjestus võib kaduda ka psühholoogiliste või emotsionaalsete reageeringute tõttu, kui indiviidi "selgitavad raamistikud enam ei toimi"(Briggs 2003: 75), kui ta "püüab mõistuspäraselt seletada kõige nõutukstegevamaid ja kohutavaid momente" (Briggs 2003: 77). Juri Lotmani (1990: 223) väitel "on narratiivi puhul eelduseks, et tekst on sidus". C. Briggsi (2003: 77) tähelepanek, et "hirm võib tähenduslikkust naeruvääristada", kuid samas saab tulemust siiski käsitleda narratiivina (vrd Klein 2006: 14, 21-22), näitab, et narra- 
tiivi määratlemisel ei ole niivõrd oluline selle vorm, sisu või kasutusvaldkond, kuivõrd kuulaja (või uurija) eeldus, et narratiiv on üldiselt sidus - s.t narratiivi aluseks on midagi koherentset, mida esitaja ehk ei suuda (vähemalt sel korral) representeerida. Siin on otsene seos Juri Lotmani (1990: 128) 'semiootilise eeldusega' - s.t üritatav kommunikatsioon on tähenduse kandja ja märgiline. Narratiiv ei ole objektiivselt määratletav, vaid ilmneb kui tulemus, mis on taotluslikult narratiivne paratamatult subjektiivses protsessis.

\section{Taotluslik narratiivsus}

Tavaliselt näime olevat häälestunud mittekõnelisele olekule, kuid niipea, kuid helide voog annab kasvõi kõige väiksema vihje, et see võib kanda ka keelelist informatsiooni, lülitume automaatselt kõnelainele: olles eemal akustilisest signaalist, kuulame tähelepanelikult neid lihaste liigutusi, mis näisid seda [häält] tekitavat (isegi käsitsi maalitud spektrogrammide puhul); ja neist elementaarsetest liigutustest eemal kuulame nende ühist eesmärki, foneemide järjestust (Tsur 1992b: 11, algautori rõhuasetus).

Narratiivse taotluslikkuse omistamist ja sellele järgnevat konkreetse tulemuse tõlgendust narratiivina võib võrrelda helimustrite vastuvõtmise ja tõlgendamisega, s.o variant verbaalsest formuleerimisest. Kuuldud akustilised sõnumid ei ole tavaliselt vastavuses meie tajutavate foneemidega (vt Tsur 1992b): teisisõnu - me konstrueerime sõnu ja väljendeid, mida arvame kõnelejat ütlevat, ja teeme seda füüsiliselt tajutud akustiliste signaalide põhjal. Samamoodi ei sõltu narratiiv niivõrd konkreetse tulemuse kindlatest tunnustest või omadustest, mida saab süsteemselt kategoriseerida ja kvantifitseerida, vaid sellest, kuidas konkreetset tulemust vastu võetakse. Narratiivi määratlus põhineb semiootilisuse eeldusel: uurija jälgib eemalt unikaalset elementide kombinatsiooni, mis on paindlike sotsiaalsete ressursside (kultuurialased teadmised ja kommunikatiivne pädevuse) tulemus, millele tuginedes näib indiviid midagi ütlevat nende spetsiifiliste väljendite abil, mida ta näib üritavat väljendada; seejärel teeb uurija järelduse, milline on nende paindlike sotsiaalsete ressursside ja üritatavate väljenduste ühine eesmärk - narratiiv kui kommunikatsioon. Ülatoodut selgitab kõnekalt Robert N. Rossi (1975: 2) lihtne näide kõrvutatud elementidest, mis on eriti hea seetõttu, et puuduvad süntaktilised markerid:

Joe, auto. Oh ei. Oijah. Oh, hea küll.

Semiootilisuse eeldus sunnib meid andma sellele järjestusele tähenduslikkust. Kuulates konkreetseid sõnalisi elemente eemalt ning järgides paindlikke sotsiaalseid ressursse, mida saab rakendada kommunikatsioonistrateegiatena, 
leiame üles ja märkame kommunikatsiooni märkivaid vihjeid. Vokatiiv "Joe" ja korduv hüüatus "Oh" viitab otsese kõne imitatsioonile ning jagab antud järjestuse seeriaks, mis koosneb neljast tagasihoidlikust artikulatsioonist:

- Joe, auto.

-Oh ei.

- Oijah.

- Oh, hea küll.

Semiootilisuse presumptsioon viib omakorda eelduseni, et selles otsese kõne imitatsioonide loendis on koherents olemas. Jälgides neid ühise eesmärgiga lühiartikulatsioone näme, et on olemas korrelatsioon loendi järjestikuste artikulatsioonide kui dialoogide vahel, s.t sõnad jagunevad kahe või enama hääle vahel. Dialoog on narratiivne strateegia, mis viib narratiivse kavatsuslikkuseni, ja sel hetkel me hakkame lugema ridade vahelt, luues eksplitsiitsete elementide oletuslike suhete ja nende koostoime kaudu narratiivse kommunikatsiooni: dialoog omistatakse (kahele) tegelasele, see puudutab autot, mis on kõnelejatele oluline, (eeldatavalt) ka sündmust, mis on selle autoga seotud ning (ilmselt) lõpeb see dialoog Joele ebameeldiva olukorraga, millest teda teavitati esimese lausega.

\section{Ootused}

Meie teadmine [---] sisaldab endas automaatselt informatsiooni tekstist, selle võimaliku olukorra, konteksti ja prototüüpsete (teiste) tegevuste, omaduste ja osalejate representatsioonides, nii et teksti representatsioon [---] on palju rikkam kui tekst ise (van Dijk 1980: 241, autori rõhuasetus).

Robert Ross (1975) on pakkunud välja termini 'ootuste struktuurid', tähistamaks kultuuriliselt sõltuvat mitte-süntaktilist arusaamist keelelisest mustrist, mida kasutatakse nii kogemuste keeles kodeerimise protsessis kui ka teiste poolt kommunikeeritud narratiivse informatsiooni dekodeerimisel. Teisisõnu annab lausungite-vahelise sidekoena toimiv 'ootuste struktuur' raamistiku järelduste ja seoste genereerimiseks, et moodustada kommunikeeritud elementide kogumist sidus tervik, k.a semiootilise olulisuse hierarhiad nende elementide vahel, mis moodustavad kommunikatsiooni (näit ülaltoodud näites on kõigi järgnevate lausungite puhul oluline "auto"). Seda protsessi, vastavaid skeeme ja makrostruktuure on süvitsi uurinud Teun van Dijk (1980), kes rõhutab, et omandatud teadmise mustrid sõltuvad kehalisest sotsiaalsest kogemusest ja diskursuses osalemisest (vrd Johnson 1987). Ta näitab, et kogemuste maailm ja maailmade fragmendid, mida diskursuse käigus tekitatakse 
või kommunikeeritakse, moodustavad kultuuris kontiinumi. Sotsiaalsed harjumused võivad seetõttu saada tähenduste elupaigaks. ${ }^{6}$ Üldised strateegiad, nagu sotsiaalsete tavade süsteemidki, on praktikas kasutatavad paindlike sotsiaalsete ressurssidena. Ootused on seotud propositsionaalse informatsiooni ja selle korraldamisega: ootuse struktuurid võimaldavad kindlaks määrata kommunikatsiooni vormi ja subsistentsi faktilise ja deskriptiivse informatsiooniga, et luua ootuspäraseid tähenduslikke tervikuid, kuid neid võib kirjeldada ka millegina, mis tegelevad pigem 'tähenduse loomisega' kui 'olulisusega'.

Anna-Leena Siikala (1990) sünteesis van Dijki uurimuse Lauri Honko seletusega kommunikatiivsuse jaotumisest žanrite vahel, mille kaudu iga žanr käsitleb mingit teemat erinevalt, võttes arvesse erinevaid aspekte ja dimensioone, väljendades erinevaid suhtumisi või rõhuasetusi, ning kaldub tegema ka mitmesuguseid väljajätteid. ${ }^{7}$ Selline kommunikatiivsuse jaotus kuulub evolutsioonilise protsessina žanri ajalukku ning selle konventsioonide, traditsioonikandjate ja vastastikuste suhete võrgustikku. Kuna žanrid on esteetiliselt markeeritud kommunikatsioonivahendid, aktiveerivad ja peegeldavad nende vihjed ja märksõnad ootusi - ootused on samas justkui tõlgendav raamistik millega suhestudes saadakse aru mingist esitusest või kommunikatsioonist (Bauman \& Briggs 1990: 73). Vihjete ja märksõnade äratundmine võimaldab kuulajaskonnal konstrueerida 'maailma fragmendi' vastavalt neile strateegiatele, mis kommunikatsiooni genereerisid, ja eeldada, et esteetilise ja retoorilise mõju saavutamiseks kasutatakse konventsionaalseid struktuure ja strateegiaid. Seda on iseäranis oluline teada, kui käsitletakse rituaalisüsteeme, kus märgid, nende kogumid ja ootused, mis tekitavad nende ümber siduva koe, erinevad radikaalselt tavakasutusest (vt Bell 1992: 94-142).

\section{Ootuste vormid ja olulisus}

Ootused toimivad kui stimuleeriv raamistik, mille abil transleeritakse tekst narratiiviks. Nad funktsioneerivad ka stimuleeriva raamistikuna, mille kaudu me vastavalt transleerime kogemuse tähenduslikeks süsteemideks, mida saab tõlgendada ning milles on võimalik edukalt navigeerida, alates tassi kohvi tellimisest restoranis kuni urisevast koerast möödumiseni pargis. Ootused näivad funktsioneerivat kolmes peamises vormis: indeksiaalses, dialoogilises ja organisatsioonilises/strukturaalses.

Indeksiaalsus on elementide ilmumise või kasutamise regulaarsuse tagajärg. Klassikaline näide on indeksiaalne seos suitsu ja tule puhul: ühe ilmnemine kätkeb endas ka teist (Peirce 1940: 107-111). Kui indeks on seotud kontekstiga, võib ta ilmneda preskriptiivselt, näiteks sõnal formula ('valem', 'vormel') on konkreetne tähendus, mida kasutatakse erinevatel puhkudel, kuid 
termini kasutamine suulise poeetika kontekstis on spetsiifiline. Nende kõrvutine kasutamine tekitab indeksiaalse suhte vormeli (termin) ja suulise poeetika (subjekt) vahel. Termini kasutamine subjektina suulise poeetika kontekstis aktiveerib indeksi ja toob kommunikatsiooni sisse rafineeritud tähenduse, mis erineb keemia-alasesse diskussiooni, armastusromaane või beebitoitu puudutavasse arutelusse lisanduvast mõttest või tähendusest. Sageli funktsioneerib indeks determinandina, määratledes sümboli väärtuse võimaliku semantilise olulisuse fraktaalses kontinuiteedis.

Dialoogiline on toimimine siis, kui elementidevaheline interaktsioon on vastastikune ja lõpeb terviku konstrueerimisega, mis on suurem kui selle osade summa. See on kõige ilmselgem eksplitsiitsete propositsioonide sidekoe lahtimõtestamises, näiteks: "Johanna oli kodus. Nägin pargis ulguvat koera." Narratiivsuse taotluslikkusest lähtudes eeldatakse, et kaks lausungit on asjakohased mingi ühise väite puhul, siinsed kätkevad propositsionaalset informatsiooni, kuid relevantne süntaks puudub, näiteks: "Ma läksin läbi pargi Johannale koju külla." Seda propositsionaalset informatsiooni tõlgendatakse kommunikatsioonis implitsiitsena.

Organisatoorne või strukturaalne funktsioneerimine ilmneb skeemide või mustrite järjestikuses progressioonis aktiveerimise kaudu, ning neid saab projitseerida (narratiivses või kogemuslikus) ajas. Need hõlmavad nt ülaltoodud dialooginäite äratundmist, või olukorda rahvajutus, kus ebaõnnele järgneb õnn, või tervendamisriituse lõpuleviimist haigustekitaja väljaajamisega.

\section{Narratiiv ja kogemus}

Karin Aronsson (2001:10288) on täheldanud, et tänapäeva ühiskonnas domineerivad inimesed, kes kasutavad narratiivi igasugustes kontekstides: "narratiive saab vaadelda kui endale-millegi-omistamise ja enese-projitseerimise lahinguvälju, isegi siis, kui mõned neist lahingutest on kaudsed või varjatud." Klein (2006: 11) toob tabavalt välja, et K. Aronssoni tähelepanek ei ole üldiselt asjakohane paljude ilukirjanduslike narratiivižanrite puhul. ${ }^{8}$ Käibelolevad narratiivid toimivad pidevalt nii ebateadlikult kui teadlikult reflektiivsete mallidena rollide, identiteetide ja kogemuste suhtes ning ka tegevusmudelitena (Stark 2006: 87-115). Eepilised ja mütoloogilised narratiivid on müütiliste proportsioonide mudeleiks, mis pakuvad võimalikke variante sotsiaalseteks rollideks ja identiteetideks, sotsiaalseid mustreid suhtluseks ja kogemuseks: nad tekitavad rudimentaarse struktuuri ja assotsiatsioonide süsteemi, mis on aluseks kultuuri (eemilisele) mõistmisele ning 'kultuuri' ja 'mitte-kultuuri', samuti 'kultuuri' ning füüsilise ja nähtamatu maailma vaheliste suhete (eemilisele) 
mõistmisele - lisaks füüsilise ja nähtamatu maailma mõistmisele (Siikala 1978; Honko 1998; Doty 2000; Siikala 2002; Tarkka 2005). Eriomased narratiivid ja jutustamise tavastrateegiad tekitavad ka indeksiaalseid seoseid rollide ja indiviidide identiteediga, kes neid ühiskonnas esitavad, ning nende esitamine seostub rollide võtmisega (Siikala 1978; Biddle 1979; Kaivola-Bregenhøj 1996). Näib olevat üsna mõistlik pakkuda, et narratiivil kui sotsiaalsel fenomenil on tähtis roll indiviidi kohanemisel kultuuriga.

Barbro Klein (2006: 19) on väitnud: "Oluline on saada aru kogemise ja jutustamise vastastikusest sõltuvusest." Isegi isiklikud kogemused on omavahel seotud sotsiaalsete strateegiate abil (Stahl 1977; Siikala 1990: 106-107; KaivolaBregenhøj 1996: 91-93; Klein 2006: 9). Nagu Linda Dégh (1985: 104) on öelnud:

Isiklikust kogemusest jutustamine on sotsiaalne toiming nagu mis tahes jutustus. Sellel on oma reeglid ja strateegiad. Jutustajad kohtuvad endale sobiva auditooriumiga ning saavutavad oma eesmärgi ühiste (traditsiooniliste) vahendite abil: personaalne gratifikatsioon, identiteedi esitus, staatuse tõstmine, või midagi muud, juhul, kui täidetakse kuulajate ootusi. See tähendab, et jutustamise laad, sõnavalik, fraseoloogia, stilistilised võtted, rõhuasetused peavad järgima kohalikku etiketti ja sobituma viitelise raamistikuga, mida on vorminud traditsioon.

Viiteline raamistik viib meid tagasi sotsiaalsete kommete kui tähenduse allika juurde. Raamistik on süsteem strateegiatest ja indeksiaalselt konventsionaalsest semiootikast, mida kirjeldatakse kui žanre. Need raamistikud funktsioneerivad paindlike sotsiaalsete ressurssidena, ja mis tahes sellise strateegia valimine eeldab vaikimisi koherentsuse olemasolu. Juri Lotmani (1990: 223) järgi on

narratiivi segmentide semantiline koherentsus see, mis moodustab süžee, ja süžee on narratiivse teksti puhul seaduseks, samamoodi kui süntagmaatiline korrastatus on seaduseks korrektse kõne puhul. Kui reaalsusest kõnelev narratiiv vajab süžeed (või süžeesid), ei tähenda see, et süžeed on reaalsuses immanentsed. Tõsielusündmused, mis hõivavad teatud ajalis-ruumilise kontiinumi, vormistatakse lineaarseks süžeeks narratiivse teksti abil.

Teisisõnu ei pruugi elul olla süžeed, kuid süžeesid on võimalik ellu sokutada narratiivsete representatsioonidena. Narratiiv erineb tegelikust kogemusest mitte oma ulatuse ja mõõtmete poolest, vaid samamoodi, kuidas libreto representeerib etenduse ühte taset või aspekti. Narratiiv esitab piiratud arvu kommunikatsiooniks olulisi elemente, kontrastina kogemuslikule reaalsusele, mis pakub täieliku spektri elementidest, mis avalduvad kogemuslikus reaalsuses. Seega saab esitatud elemente pidada selektiivse protsessi tulemiks. See prot- 
sess hõlmab implitsiitselt ka elementide semiotiseerimist (Lotman 1990: 133134) - elemendid muutuvad selliseks, et nad suudavad midagi märgistada või tähistada. See aga ei tähenda, nagu oleks konstitueerivatel elementidel kõigil ilmtingimata semiootiline tähtsus, vaid pigem seda, et neil on see potentsiaalselt olemas - narratiivi akt viitab olulisusele ja võib täita need järjestikused sündmused 'tähendusega' isegi siis, kui see olulisus lipsab jutustaja käest ära.

Üldised raamistikud ja väljenduslaadid loovad tavasid, mis mõjutavad representatsiooni ja tekitavad (sotsiaalse fenomenina) preskriptiivsed mustrid selle kohta, millised elemendid on semiootiliselt olulised ja millised mitte (Lotman 1990: 217-220). Jutustamise ja tõlgendamise protsess peegeldab subjektiivse 'kogemise' kultuurilisi mustreid, mis on tegelikult oluliste elementide filtreerimine mitteolulistest narratiivsete strateegiate lisafiltri abil. ${ }^{9}$ Ootuste (struktuuride) kirjeldus ja analüüs annab raamistiku, mõistmaks narratiivi loomise ja retseptsiooni protsessi, mis ulatub kogemuseni. Kuid samamoodi nagu V. Proppi selgitused rahvajuttude süntaksi ja grammatika kohta, ei võimalda need tähenduse loomist narratiivi abil (vrd Johnson 1987; Suojanen 1993:105). Kui narratiivseid strateegiaid kasutatakse tähendusliku kogemuse aktualiseerimiseks (või sellise kogemuse aktualiseerimiseks, mida teised tajuvad tähenduslikuna), on ootuste struktuurid pelgalt põhjusliku progressiooni mehhanismid, mis sageli näivad empiiriliselt ebaloogilised. Näiteks on võimalik käsitada nende 'lavastamist' kui mehaanilist strateegiat, et saavutada mingi maagiline tagajärg - et nii-öelda elada anekdoodis. See näide on tegelikult sama kohmakas kui muna purukslöömine haamriga endastmõistetaval põhjusel. See mehaaniline mudel ei selgita, miks või kuidas peaksid armastust või kiindumust väljendavad strateegiad funktsioneerima filmide, raamatute või anekdootide narratiivsetes stsenaariumides; see ei selgita ka, miks või kuivõrd tuleks omistada tähendust personaalset mudelit intiimsemalt imiteerivatele strateegiatele, näiteks vanemate või vanavanemate koostatud kurameerimisplaanile. Niisamuti on tõene, et eepilised ja mütoloogilised narratiivid loovad alusstruktuure ja assotsiatsioonide süsteeme, mis sageli kajastuvad ootustena teistes žanrites ja isiklikus kogemuses oma kultuurikeskkonnas, kuid need ootused ei näita, miks see peaks nii olema.

\section{Narratiivne vägi}

Üldtuntud, ent teadustöös sageli eiratud tõde on, et see, kuidas midagi öeldakse, on osa sellest, mida öeldakse (Hymes 1986: 59).

Semiootiliselt eristatavad elemendid laetakse (Lifton 1961: 429-30) vastavalt nende tavapärastele kasutusmustritele konkreetses kommunikatiivses kontekstis, näiteks mingi üldise kommunikatsioonistrateegia raames, või rühma- 
siseselt (s.t vastavalt indeksile). See annab neile elementidele võimaluse tuua kommunikatsiooniprotsessi informatsiooni, väärtuste, assotsiatsioonide ja implikatsioonide pakett. See pakett hõlmab mitte-propositsionaalset teavet, mille puhul sageli välditakse kirjeldusi, või mida kirjeldatakse metafooriliselt kui retoorilise, esteetilise ja maagilise efektiga ‘jõudu' või 'väge'.

Narratiivse väe põhimõtted on sarnased John Mile Foley (1992; 1995) sõna võimu teoorias sätestatule. Sõna võim on termin ja strateegia käsitlemaks mitte-propositsionaalset informatsiooni, mis ilmutab end keele tüpoloogiates ja keelekasutuse tüpoloogiates. Kõige olulisema uuendusena näitas J. Foley, et leksikaalsed ühikud ja suuremad väljendusüksused (näiteks vormelid) ei ole ainsad sõna võimu kandjad: registrid, meetrika ja poeetilised süsteemid üldisemalt suudavad luua väärtusi, assotsiatsioone ja implikatsioone, ning need kommunikatsiooni sisse tuua (vrd Frog 2009b: 224-227). Õigemini on need väärtuste, assotsiatsioonide ja implikatsioonide süsteemid internaliseeritud vastavalt individuaalse kasutuse indeksitele, ning just asjakohaste ja sobivate indeksite aktiveerimine laeb kommunikatsiooni sõna jõuga. J. Foley väidab, et "sõna jõud tuleneb esitust võimaldanud sündmusest ja traditsiooni võimaldavast referendist” (Foley 1995: 213) - ehk teisisõnu, esitus (kasutamine üldisemalt) võimaldab aktiveerida asjakohast indeksit või indekseid, mis on tekkinud konkreetse traditsioonisüsteemi regulaarsetes kasutusmustrites.

J. Foley teooria oli esimene, mis visandas sidusa deskriptiivse strateegia, käsitlemaks selliseid mitte-propositsionaalseid tähenduspakette, mida väljendatakse traditsiooniliste väljenduslaadide abil. Lauri Honko (1998: 96-97; 2003: 113) rõhutas, et kujundid säilitasid järjepidevalt oma kultuurilise laetuse, mis ei sõltunud konkreetsest (või mis tahes) verbaalsest väljenduslaadist. Tähistamaks neid süsteeme, mille kaudu kujundid laetakse traditsiooniga, pakkus ta välja väljendi kujundi jõud. ${ }^{10}$ David Frankfurter (1995) võttis maagilise rakenduse puhul kasutusele termini narratiivne vägi. ${ }^{11}$ Narratiivse väe kasutamine maagias annab võimaluse käsitleda mitte-propositsionaalset tähendust, mida saab sisse tuua narratiivi abil, kuna narratiivil arvatakse olevat mitte retooriline või emotiivne mõju, vaid ka võime otseselt mõjutada füüsilist maailma see on jõud või vägi, mis on kõrgemal narratiivi propositsionaalsest sisust. ${ }^{12}$ Lea Olsan (1992: 129) täheldab, et loitsu-historiolade traditsioonis näib manipuleeritavate motiivi-komplekside arv olevat piiratud. Need vähesed motiivid, mida kasutatakse, ja nende regulaarsed rakendamismustrid võimaldavad neil tekitada kompositsioonilise elemendina narratiivse väe indeksiaalse laetuse. L. Olsan (1992: 130) näitab, et teatud kogum historiolasid võib olla piisavalt laetud narratiivse väega, toimimaks metonüümilise tervikuna. ${ }^{13} \mathrm{D}$. Frankfurter (1995: 458-459) täheldas, et narratiivse väega laetus, mida hoiavad ülal narratiivsed elemendid, säilib tervikust sõltumata ka siis, kui ta kantakse üle 
uutesse kontekstidesse ja rakendustesse, s.t kui luuakse 'uued' historiolad, mis on maagiliselt efektiivsed tänu individuaalsete motiivi-komplekside narratiivele väele historiola kasutamise indeksis (ega nõua referendina laiemat narratiivset üksust).

On võimalik eristada erinevaid narratiivseid strateegiaid, struktuure ja nende osiseid, mis laetakse narratiivse väega vastavalt nende kasutusmustritele, ning tekstilisi ja tekstiväliseid narratiivseid üksusi, mis võivad olla samamoodi laetud oma kultuurilise tegevuse kaudu. ${ }^{14}$ Sõna jõu, kujundi jõu ja narratiivse väe (ja ka heli jõu, mida siinkohal ei käsitleta) äratundmine ühes dokumenteeritud väljenduses ei tähenda, et oleks vaja püüda eristada, kus lõpeb üks ja algab teine - nad kombineeruvad omavahel ning tekitavad ekspressiivse terviku, kus nad suurendavad üksteise olulisust ja muutuvad vastastikku sõltuvaks. Eriti oluline on seda ära tunda riituste etendamise puhul, kus on koos kommunikatsiooni verbaalsed ja visuaalsed aspektid.

Narratiivse väe puhul on oluline mõista, et see ei ole identne narratiiviga, vaid seda manipuleeritakse narratiivide kaudu, kuid seda saab rakendada ka näiteks strateegiana, et aktualiseerida kogemust, mida tajutakse tähenduslikuna, või tuues mingil muul moel tähendusrikkust sellesse kogemusse. Riituse puhul peame silmas seda, kuidas riituse stsenaarium oma preskriptiivsete skeemidega on vastavuses ennustatavate mustritega, mis loovad raamistiku kogemusena aktualiseeritud emergentsele narratiivile. Seda saab käsitleda ja kirjeldada ootuste struktuuridena, kuid et mõista selle tähendust terviseprobleemi lahendamisel, on vaja arvestada ka narratiivse väe lisamõõdet.

\section{Tietäjä tervendamisriitused šamaaniriituste kaudu}

Ulla Piela on käsitlenud tietäjä loitsuteksti kui narratiivi, mis saab anda meile teavet riituse kohta. Pidades loitsu 'mina' tervendajaks, väidab U. Piela, et "riituse kontekstis on loitsud narratiivid, mis tervendavad" (Piela 2005: 13). U. Piela käsitlus on tegelikult radikaalselt ümbertöötatud versioon Lauri Honko (1959: 204-207; 1960) tervendamisetenduse kontseptsioonist, tuginedes AnnaLeena Siikala (1992; 2002) käsitlusele tietäja institutsioonist, mis annab ülevaate tietäja esituse verbaalse ja strukturaalse tasandi improvisatsioonilistest strateegiatest. Vastavalt U. Piela käsitlusele on loits riituse reaalajas tervendamiseks sooritatud emergentne narratiiv. L. Honko draama-analoogia on peamiselt deskriptiivne, kirjeldab riituse-etendust ja loodud rolle, U. Piela rõhutab narratiivi, mis peegeldub riituse-etenduse loitsus ravi lõpuleviimisena. U. Piela lähenemine on rohkem suunatud loitsude järjestikusele lugemisele, 
mis avaldus või avaldub narratiivina riituse esitusel. Eeldan, et narratiivne vägi on võti, saamaks aru, kuidas ja miks peeti ilmnevat/emergentset narratiivi riituse puhul efektiivseks strateegiaks. L. Honko esialgne draama-analoogia tugines võrdlusele subarktiliste šamaaniriitustega. Šamanistlike traditsioonidega tegelemine aitab üldjuhul heita valgust mõnele subtiilsemale aspektile tietäja-poolse narratiivse väe manipuleerimisel ning võimaldab tõmmata paralleele, mõistmaks paremini rakendatud strateegiaid.

\section{Šamaaniriitused kui narratiivne draama ${ }^{15}$}

Šamaani puhul on iseloomulik, et ta loob hingedemaailmaga vahetu ja vastastikuse kommunikatsiooni (Siikala 1978: 319).

Šamanistlik riitus on "püüe lahendada tavamaailma probleeme, luues ekstaatilise kontakti üleloomulikuga" (Siikala 1978: 319) ja olles vastastikuses suhtluses nähtamatu maailmaga. Eriti iseloomulik on šamanismile hingede-abiliste olemasolu ja hingede liikumine maailmade vahel, kehast välja ja tagasi, kas hinge omandamisena, šamaani hingerännakuna, või interaktsioonina nähtamatu maailma hingedega ning šamaani kulgemisega teise maailma ja sealt tagasi.

L. Honko (1969; 1972: 166-209) käsitles šamanistlikke riitusi rolliteooria seisukohalt. ${ }^{16}$ Ta väitis, et šamaan aktualiseerib oma rolli šamaanina, kui ta läheb ekstaatilisse seisundisse, mis võimaldab otsekontakti nähtamatu maailmaga. Sellise rollivõtmisega kaasneb eeldus, et hingeomandamise, abihingede ja nähtamatute vaenlastega suhtlemise protsessis on olemas ka vastasrollid. Ekstaatilise rollivõtmise ja etenduses näitlemise erinevus tuleb ilmsiks rolli aktiveerimise ja rolliga samastumise intensiivsuses (Honko 1969: 39-41). A.-L. Siikala (1978) arendas seda käsitlust edasi ja leidis, et 'rollivõtmine' on oluline kontrollitud ekstaatilise seisundi saavutamiseks. A.-L. Siikala uurimustest tuleb välja, kui oluline on see, et pühendatu internaliseeriks suulise pärimuse materjali ning mõistaks seeläbi nähtamatut maailma ja selle elanikke. A.-L. Siikala kirjeldab ekstaasi kui füsioloogilist nähtust ning ekstaasi mõju rituaalispetsialisti reaaluses orienteerumisele: laulu kasutamist ekstaatilise seisundi saavutamiseks, et šamaan keskenduks suulisele pärimusele, mille abil kommunikeeritakse tema teadmisi müütilisest maailmast, kuni ta saavutab üldistatud reaaluses orienteerumise ja "kogemused muutuvad seotuks ainult erilise orientatsiooni sfääriga, s.t šamaanliku maailmaga, mis muutub nüüd ainsaks võimalikuks reaalsuseks" (Siikala 1978: 51). Selline kontrollitud ekstaatiline seisund liigendab kogemusliku maailma struktuure ja semiootikat, lisaks kontrollitakse seda keerukate, samas asendatavate struktuuride internaliseerimise kaudu. Teisisõnu võib seda šamanistlikku maailma, sub- 
jektiivset müütilist maailma kirjeldada kollektiivse pärimuse personaalse internaliseeritud narratiivse maailmana.

Šamanistlik hingerännak teispoolsusse, sellega seonduv motiivistik ja sündmused tekitavad soovi võrrelda neid narratiiviga, on võimalik tõmmata paralleele eepilise pärimusega (vt Hatto 1970). Rituaalset šamaanietendust saab käsitleda kui kindlalt struktureeritud ja konventsionaalselt organiseeritud narratiivide järjestust, mille esituse semiootika, taasesitus ja retseptsioon muutuvad vastavalt esteetilistele kommunikatsioonivormidele ehk žanritele. ${ }^{17}$ A.-L. Siikala (1978: 320) rõhutab, et šamaanile omistatav ähvardav jõud oli oluline, et piirata erinevate improvisatsiooniliste strateegiate variatsioone riituses: konservatiivseid tavasid ei hoitud alal mitte patsiendi tõttu või sellepärast, et kõrvalekalle neist oleks võinud olla saatuslik, vaid šamaani enda pärast. Konventsionaalsed strateegiad olid tavapäraselt laetud narratiivse väega, s.t need olid efektiivsed, kuid kaasnev risk šamaanile oli minimaalne.

Draama-analoogiat ei tohiks tõlgendada kui "sümboolseid akte, mis on mõeldud mõjutama kuulajaskonda ning paluma neilt tõlgenduslikku suhtumist" (Bell 1992: 42; vrd Siikala 1978: 319-330). Rollivõtmise protsess on mitmes mõttes sarnane mängu või lavastusega, kuid šamaan samastab end rolliga sel määral, et ta sukeldub etenduse subjektiivselt konstrueeritud narratiivimaailma. Riituse stsenaarium annab narratiivse raamistiku, ja nihe reaalsusorientatsioonis võimaldab täita selle raamistiku narratiivse maailma jaoks loodud ootuste struktuuridega. Riituse produkt on emergentne narratiiv, mis ei pruugi järgida riituse stsenaariumi. Šamaan rakendab internaliseeritud strateegiad riituse kui kogemuse konkreetse, struktureeritud ja tavapäraselt korraldatud narratiivi-järjestuse aktualiseerimiseks.

A.-L. Siikala (1990 [1998]: 103-106; 2002a: 68-70) on kirjeldanud seda protsessi kui suunatud kujutlusvõimet, kus šamaan loob erinevate strateegiate abil mitmeid vastasrolle. Tavastrateegia, mida šamaan kasutab konkreetses miljöös, on vähemoluline kui tõik, et need strateegiad nii kavandavad kui ka reflekteerivad narratiivide maailma, millesse šamaan on sukeldunud. Rollid luuakse vastavalt sellele, millist käitumist eeldab ja/või nõuab konkreetne interaktsiooniolukord (Sarbin 1954: 225; Honko 1969: 36; Siikala 1978: 54; Biddle 1979: 58 jj). A.-L. Siikala rõhutab, et need vastasrollid on traditsioonilised, neid tuleb õppida nagu sotsiaalseidki rolle - s.t et abihing ei ole mitte lind või põhjapõder, vaid roll, millel on oodatav käitumismuster ja võime. Võrreldes tavapäraste rollidega kogukonnas on nende rollide internaliseerimine subjektiivsem, sest tegu on nähtamatu maailma elanikega. Seega ei ole suurt erinevust rollide kavandamises ja kasutamises inimkogukonnas ja nende käitumisskeemide vahel, mida kavandatakse nähtamatu maailma elanikega suhtlemisel - välja arvatud see, mil määral on võimalik ette näha, et interaktsioon nähtamatu maailma elanikega vastab teatud paradigmadele. Tundub mõistlik 
üldistada, et rollid, mis on subjektiivselt loodud, vastavad tõenäolisemalt ja etteaimatavalt rohkem skeemidele kui inimkogukonnas võetud rollid, mille puhul kaasneb interaktsiooniga väga palju erinevaid tegureid.

Šamaan näib oma reaalsusorientatsioonis pöörduvat inimestevahelisest interaktsioonist fokuseeritud suhtlusele nähtamatu maailma elanikega. Sellega kaasneb nihe käitumise semiootikas ja ootustes, kuid strateegiad (tegevused ja kõneaktid), mida kasutatakse etteaimatava interaktsiooni algatamiseks, on põhimõtteliselt samad. Kuid sel juhul ei ole vastasrollidel konkreetseid esindajaid kogemuslikus maailmas. Tõik, et vastasrollid luuakse subjektiivselt, ei tähenda, et need oleksid vähem reaalsed. Draama-analoogia põhjal võib kergesti teha eksiteele viiva järelduse, et etendus on imiteeriv ja kommunikatiivne, mitte teatud tegevus, isegi kui see toimub vaid nähtamatus maailmas: etendust tuleb käsitleda kui teatud mustrit või retsiprookset interaktsiooni.

Šamaan siseneb narratiivimaailma, aktiveerides oma rolli ekstaatilise teispoolsuse vahendajana, samuti aktualiseerib ta erinevad vastasrollid, mida tajutakse subjektiivselt nähtamatus maailmas. Vastasrollid kohandatakse ja luuakse vastavalt interaktsiooniolukorda sobivale käitumismustrile. Toetav või vaenav interaktsioon vastasrollidega toimub vastavalt sellele, milline on sotsiaalse suhtluse soovitud tulemus: šamaani tegevused toovad välja nähtamatu maailma vastasrollide vastused ja reaktsioonid. Inimkogukonnas on selliste interaktsioonistrateegiate kasutamisel soovitud reageeringu, tulemuse või vastutegevuse saamiseks erinev tõenäosus. Šamaani subjektiivse projektsioonina kaob erinevus selle vahel, milline on vastasrollilt soovitud tõenäoline reageering, ja šamaani-poolse maagilise sundimise tulemusena saadud oodatav reageering, vastutegevus või tulemus. Vastasroll on suuresti subjektiivselt konstrueeritud, internaliseerides nähtamatut maailma kui narratiivi, ja kui vastandrolli ettearvamatust suurendavad tegurid on kõrvaldatud, tagatakse narratiivse väe kasutamisel vajalik efekt. Improviseeritud etenduse struktureerimisel kasutatakse mitmeid strateegiaid ja väljenduslaade. Selline etenduse-kogemus ei ole vähem unikaalne kui näiteks restorani külastades toimuv interaktsioon restoraniomaniku või kelneriga. Šamaani-etendus peegeldab interaktsiooni subjektiivselt tajutud narratiivse maailmaga, ka siis, kui šamaan vahendab seda publikule, kes ei näe seda võõrustajat, kelnerit, kokka või magustoiduvaagnat ja kroonlühtrit. Erinevate internaliseerimisstrateegiate, teadmiste ja arusaamise tulemusena kasutatakse narratiivset väge alates dialoogitasandist kuni riituse kui tervikuni, tekib sidus järjestus, mis loobki emergentse narratiivi. Erinevalt rahvajutust või memoraadist aktualiseeritakse selline dünaamiline etendus kui kogemus, mis leiab aset publiku ja šamaani reaalajas. 


\section{Tietäjä ja narratiiv riituse kontekstis}

Tietäjä institutsioon rituaalispetsialistina tekkis koos meetriliste loitsude kasutuselevõtu ja/või nende olulisuse suurenemisega nähtamatu maailmaga suhtlemisel (vt Siikala 2002a). Nähtamatu maailmaga suhtlemisel kasutas tietäja mitte isiklikku või vahendatud hingerännakut teise ilma, vaid meetrilist loitsu, kui peamist vahendit nähtamatu maailmaga suhtlemisel. Ühelt poolt on see kunst segu subarktilisest šamanismist ja Euroopa loitsimistraditsioonist, kuid teisalt ei mahu tietäja kunst kummassegi kategooriasse nende konventsionaalses vormis. Euroopa loitsutraditsioonis sõltub sõna jõud retsitatsiooni täpsusest (memoriseerimisest). Selliste loitsude puhul ei ole vaja rituaalispetsialisti; etenduse maagiline efekt saavutatakse peaaegu mehhaaniliselt (Hästesko 1918: 28), ilma et oleks vaja aru saada nähtamatust maailmast või kasutatavatest sõnadest. Kuigi meeldejäetud loitsud olid läänepoolses Soome-Karjala osas valdavad 18. ja 19. sajandil, säilis idapoolsetel aladel tietäja tähtsus rituaalispetsialistina kauem. Tietäja loitsud olid erinevad improviseeritud esitused, mis sõltusid tema sisemisest maagilisest jõust. Loitsude efektiivsus tugines teadmistele, loitsudes kasutatavate sõnade ja motiivide mõistmisele ning teispoolsusest ja selle elanikest arusaamisele (Siikala 1986: 187-90). Termin tietäjä tähendab 'teadjat' või 'seda, kes teab':

Tulevane tietäjä ei õppinud haiguste diagnoosimist, loitsuvormeleid ja maagilisi protseduure lihtsalt pähe, vaid internaliseeris ja organiseeris teispoolsusega seotud teadmised, selle asukad ja topograafia orgaaniliselt omaenda maailmapilti (Siikala 2002a:84).

Tietäjä esitas loitsud ekstaatilises transiseisundis, ning arvati, et ta avab suhtluskanali teispoolsusega, kuid teistmoodi kui šamaan. Tietäja loitsude tõhusus ja riituse tehnikad sõltusid pädevusest, mis võimaldas tal sooritada asjakohaseid tegevusi ja improviseerida tekste vastavalt vajadusele. Nagu šamanistlikus traditsioonis, anti need teadmised edasi narratiivi ja lauluga, nii eepiliselt kui ka loitsudena (Siikala 2002a: 330-331). Tietäjä täiendas pidevalt oma teadmisi poeetilisest süsteemist ja vastavatest žanritest ning riituses kasutatavatest tehnikatest. Tuleb rõhutada, et poeetilises traditsioonis on eepika ja loitsud tihedalt seotud (Tarkka 2005: 70-72). Eepilist pärimust ei kasutatud mitte ainult loitsudes: see oli suunatud tietäjä-kangelase, mitte vägitükke tegevate ja sõjalisi oskusi demonstreerivate sõjakangelaste kuvandi ja kontseptsiooni edasiandmisele (vrd Comparetti 1898; Hatto 1970: 6-7). Eepika väärtuslikkus sundis tietäjät saama selle ala spetsialistiks, tietäjä institutsioon näib olevat üldiselt mõjuvõimas kanal eepika edasiandmiseks. ${ }^{18}$ 
Eepiline ja müütiline narratiivne materjal pakkus maagilisteks etendusteks väärtuslikku ainest. Mütoloogilise narratiivi tähtsus tietäjö esitustes avaldus ka loitsu-historiolade muutumises teiste mütoloogiliste narratiividega võrreldava pikkusega looks ning selles, et mõned mütoloogilised narratiivid näivad olevat püsinud (peaaegu) eranditult meetriliste historioladena (vrd Tarkka 2005: 150).

\section{Narratiiv narratiivis: historiolade roll}

Historiolasid seostatakse üldiselt tervendava maagiaga (Frankfurter 1995: 461; Roper 2005: 91). Historiola on maagilisel eesmärgil kasutatav narratiiv. Enamasti on historiola loitsu või loitsimise osa, mis loob sidusa terviku koos teiste maagiliste sõnade ja tegudega (vrd Siikala 1991; 2002a; Roper 2005: 69-75). Koos riituse verbaalsete ja esituslike lisaelementidega loob historiola eelduse sidususeks ja taotluslikuks narratiivsuseks, s.t et müütiline narratiiv on oluline tervikus, mille kolme põhitüüpi käsitletakse järgnevalt.

\section{Historiola kui tervendamisdraama}

Euroopa loitsutraditsiooni puhul eeldatakse tavaliselt, et historiola on müütiline mudel, mis muudab tervendamiskatsed edukaks (Frankfurter 1995: 461466; Roper 2005: 91): ur-akti itereerimine tagab loitsu positiivse mõju. Enamasti on see nii loitsudes, kus historiola kulmineerudes või lõppedes kasutatakse tervendavaid sõnu, mis on sageli implitsiitse ja eksplitsiitse kõneaktina narratiivi sees. Kogu etendust võib käsitleda kui algsündmuse taasesitust.

Lotte Tarkka (2005) on rõhutanud, et Karjala eepika ja loitsude esitajad samastasid end eepiliste kangelastega, mõjutades nii nende representatsiooni: andes hääle müütiliste kangelaste verbaalsetele väljendustele, olid nad osalised rollivõtmise ja identiteedi vastastikuses mõjutamises. Selline dubleeriv tegevus (Tarkka 2005) või topelttegevus (Lönnroth 1978) tekitab järjekestvuse riitusega ja ühendab historiola müütilise akti etenduse olevikuga, kui esitaja annab hääle algsündmuses kasutatud maagilistele sõnadele (vt ka Frankfurter 1995 ja seal viidatud töid; Roper 2005: 91). Müütilise mudeli ja tervendamisakti vahel tekitatud järjepidevus liigub ühest prototüübist või pretsedendist edasi nii, et kaob erinevus müütilise mudeli ja praeguse tegevuse vahel. Mudeli narratiivne vägi kutsub šamanistlikes riituseetendustes esile etteaimatavaid, kuid siiski erinevaid reageeringuid vastasrollides, ning lõpptulemuseks on kogemusena aktualiseeritud draama. Äsjakirjeldatud historiola-loitsus kasutatakse riituse etendamisel müütilise sündmuse narratiivset väge kui mudelit, mis teatud mõttes taasesitatakse, kulmineerides selle edukaks tervendamisaktiks. Narratiivi käigus lausutud müütiliste tegelaste tervendamis- 
sõnu ei omistata lihtsalt kõnelejale, vaid kõneleja võtab need omaks ja rakendab neid aktiivselt, luues (enam-vähem) täieliku samasuse historiola müütilise sündmuse ja esitaja tervendamisakti vahel. See samasus tagab eduka tervendamise, see on narratiivse väega laetud müütilise mudeli kasutamise tagajärg; narratiivne vägi on sama kaheldamatu kui ajalugu.

Kasutusmustrite ajalooline järjepidevus toob ilmsiks maagilise jõu järjekestvuse, konkreetse historiola narratiivse väe mõjujõu või tõhususe. Kuid ei ole põhjust uskuda, et konventsionaalsete sümbolite, narratiivide ja nende kogumitega manipuleerimist maagilise toime saavutamiseks tõlgendati vaid ühtviisi konventsionaalselt (vt Bell 1992: 182-187). On mõistlik eeldada, et narratiivse väe järjekestvus historiolas eeldas sidusust, kuid see koherentsus võib olla näiteks tervendamissõnade edasiandmise järjekestvus alates algtervendamisest või mingi üldisem analoogia. Oleks vale eeldada, et igal selle loitsu tarvitajal oli ühetaoline arusaam sellest, kuidas ja miks oli see tõhus. ${ }^{19}$

\section{Abstraktsioonid}

Euroopa loitsutraditsioonis oli kaheldamatult mitmeid juhtumeid, kus historiola loodi lihtsalt loitsusõnade ütlemisega, saamata hästi aru, et sellel tervikul on tegelikult maagilised tagajärjed (vrd Frog 2009a). Puudus vajadus mõista loitsu sõnu või sisu või nende suhet nähtamatu maailmaga: korrastatud ja väljaöeldud sõnad ja narratiivid olid ise tõhus väeinstrument. H. S. Versnel (2002: 126-130) on rõhutanud, et üksikut historiolat võib "meelevaldselt" siirata ühest tervendamiseaktist teise. See on omane narratiivile või mingi narratiivi osale (vrd Roper 2005: 124-125), mis toimib narratiivse jõu dünaamilise allikana. Lea Olsan on rõhutanud, et see näiline meelevaldsus toimib seetõttu, et haiguse ja historiola (mis tahes) motiivi vahel on indeksiaalne korrelatsioon. Motiivi korrelatsioon tekitab korrelatsiooni historiola müütilise sündmuse ja loitsu abil teostatava maagilise akti vahel. Sellisel juhul saab historiolat käsitleda loona, mis avab müütilise tegelase või sündmuse väe, kutsub seda jõudu appi, on sama-väeline, või lihtsalt evib historiola narratiivset väge, milles on palju mitte-propositsionaalset teavet, ja mis samastub/võrdub maagilise jõu või efektiivsusega (Olsan 1992: 129; vrd Eliade 1963: 21-38).

Selle variandi puhul on ootused suunatud sellele, et tekiks teatud (või mis tahes) moodus, mis ühendaks tervendamisakti väe allikaga, ilma et selleks oleks vaja koherentset arusaamist väe allikast või müütilisest maailmast. Narratiivne järjepidevus neis kasutusmustrites näib olevat pisut enam kui lihtsalt selle ühenduse väljendus: individuaalsel tasandil on vastav kasutus üsnagi abstraktne kogum "vajadustest, eesmägist ja narratiivest motiivist" (Olsan 1992: 129-130; vrd Roper 2005: 207). See näitab, et olenemata historiola traditsiooni põhialustest või nende konventsionaalsetest tõlgendustest erinevatel perioo- 
didel, võis narratiivse väe järjepidevus läbida mitmeid radikaalseid muutusi ja variatsioone selles osas, kuidas mõisteti narratiivse väe efektiivsust selle erinevates kasutustes.

\section{Sünni jõud}

Tietäjä oli ‘see, kes teab’, tema kunst tugines teadmisele ja mõistmisele. See aluspõhi, tietäja internaliseeritud teadmised, peegeldub temapoolses historiolade kasutamises, mille puhul kaob müütilise mudeli ja tervendamisakti vaheline vahemaa niivõrd, et saab väita, et see akt on (potentsiaalselt) isiklik kogemus. Tietäjä müütiliste teadmiste arsenalis on oluline roll teadmistel algupärast. Vahetud teadmised loomisest on väe ülim allikas (vt Tarkka 2005: 160-198), ja historiolad, mis jutustavad kahjutekitaja müütilisest sünnist (raud, tuli, madu jm vastandatuna müütilisele sündmusele, mis loob müütilise mudeli sellest haigustekitajast või tervendamisest) on pärimuses eriti väljapaistvad (vt Krohn 1924). F. A. Hästesko (1918: 28, 182-183) on täheldanud, et see loitsutüüp on ainuomane Soome-Karjala pärimusele. A.-L. Siikala (2002a: 89) väitel leidub paralleelseid sünniloitse vaid ajalooliselt ja geograafiliselt kaugete kultuuride pärimuses (vrd Haavio 1967: 343-344). A.-L. Siikala (2002a: 89-90) arvab, et kontseptuaalne alus on seotud vastava müütilise teadmisega šamanistlikus traditsioonis, kus teadmistel haigustekitaja algupärast ja genealoogiast on oluline roll müütilisse teadmisse initsieerumisel: see teadmine võimaldab algatada reisi teispoolsusesse ja sundida haigustekitajat heastama tekitatud kahju.

Šamanistliku mõtteviisi järgi ei kuulunud mingi olemi saladuslik päritolu mitte ainult selle müütilisse algusesse, vaid eksisteeris ka teispoolsuses nagu inimeste esivanemad, surnud, kes jätkavad seal oma elu - ja seega saavad nendega kontakti need, kes on suutelised suhtlema üleloomulikuga (Siikala 2002a: 90).

Karjala sünnisõnad näivad teatud tunnuste osas olevat pärit varasemast šamanistlikust kultuurimiljööst. Mingil strateegial võivad olla küll ajaloolised juured, kuid see ei tähenda, et seda rakendati ja kasutati sidusalt ja järjepidevalt või et seda kasutas mingil perioodil iga inimene. Sünnisõnad säilitasid selgelt narratiivse väe järjepidevuse pärimuses, kuid ei ole selge, et nende narratiivsest väest ka järjekindlalt aru saadi.

\section{Historiolad tietäja tervendamisriitustes}

Arusaamine historiola ja selle kasutamise seostest oli subjektiivne. Käsitledes esitaja samastumist müütilisest tarkusest kõnelejaga ja vastavat järjepidevust, pöörab L. Tarkka (2005: 150-151) tähelepanu asjaolule, et narratiivsete 
elementide kasutamisel hakati Karjala traditsioonis kolmanda isiku asemel kõnelema esimeses isikus. Ta toob näite Väinämöise põlvehaavast, veresõnadest, kus narratiiv esitatakse eranditult esimeses isikus ja konventsionaalset müütilist protagonisti Väinamöist ennast ei mainitagi (SKVR I1 196): historiola protagonisti-roll samastub täielikult esitajaga. Sellise kasutuse puhul jääb ebaselgeks, kas esitaja võtab omaks rolli ja ka müütilise tegelase identiteedi, või vastupidi, võtab endale küll rolli ja asendab müütilise tegelase omaenda minaga. See tõstatab olulise küsimuse, kuidas mõisteti historiola ja esitaja vahelist suhet.

Sünnisõnade kasutamise järjepidevus võib olla seotud sellega, et haigustekitaja genealoogiat mõisteti kui kontrollivahendit: narratiiv manifesteerub kui tööriist, mis annab kõnelejale võimu objekti üle. Seega annab algupära ka seletuse haigustekitaja ilmumisest maailma ja tekitab järjepidevuse haigustekitaja avaldumisel või kahju tekitamisel inimkogukonnale. L. Honko (1959: 126-128) seostab sünnisõnad (muistse) pärimusega, mis kirjeldab nähtuste ahelat, ühendades haigustekitaja maailma loomisega iidsetes kultuurides, ning seob haigustekitaja osavalt maailmaloomise väega. Need näited ei keskendu paraku mitte ühele, vaid mitmele järjestikusele sündmusele, mis haigustekitajas kulmineeruvad. Karjala sünnisõnad on tavaliselt omaette müütilised sündmused, mis ei ulatu tagasi loomise aega ning on seetõttu sarnasemad A.-L. Siikala võrdlustele. Kuid "Loomise laulu” saab kasutada historiolana või lõimida historioladesse, ühendades need maailma esmaloomisega. See avaldub eraldi strateegiana ja põhineb maailma-loomise väel.

Kui "Loomise lauluga" tuuakse sisse sünnisõnad, stimuleerib taotluslik narratiivsus narratiivse järjepidevuse tajumist alates maailma loomisest kuni haigustekitaja algupärani, luues ühenduse selle sünni ja maailma alguse vahel, mis omakorda vähendab algupära olulisust genealoogia või tagasihoidliku sündmusena. Näiteks SKVR I1 35-s aktiveeritakse pisti sünd metonüümiliselt, historiola lõpeb müütilise tammepuuga, millest ta on loodud, kasutatakse ebatavalist kordust, et kutsuda välja maagiline objekt, mis peaks patsiendist maagilise pisti eemaldama. "Loomise laulu" kasutamine on selgelt seotud võimuga, mille annab teadmine algupärast. Puuduvad viited selle kohta, et see teadmine, mis viib sünni tagasi esmaloomiseni on lihtsalt moodus, kuidas suurendada võimu objekti üle: sama strateegiat kohtab ka näiteks seoses Väinamöise põlvehaavaga.

Kui sünnisõnu käsitada riituse raames narratiivide järgnevusena, stimuleerib "Loomise laulu" ja traditsioonilise historiola kõrvutamise või lõimimisega tekitatud narratiivne taotluslikkus ootusi täita lünki haigustekitaja päritolu ja selle ravimise vahel propositsionaalse informatsiooniga, mis on põhjuslikus seoses implitsiitse sündmuse (vigastuse/nakkuse) kaudu. Tervendamisriituse 
käigus tekitab historiola narratiivse järjepidevuse maailma loomise ja ravimisakti vahel - akt, mis eeldab kosmoloogilisi või isegi apokalüptilisi mõõtmeid; selle asemel, et taasesitada müütiline tervendamine, omandab riitus müütilise mudeli proportsioonid, lahendab kannatuste allika, mis on teatud mõttes olnud immanente alates maailma loomisest, ja üksnes riituse-etendus saab selle müütilise järgnevuse lõpule viia, lahendades tervisega seonduva kriisi. Samasugune skeem tekib ka Väinamöise põlvehaava seostamisel loomisega - historiola seob müütilise tervendamismudeli ülima loomisjõuga ja stimuleerib järjepidevust - maailma loomisest tervendamissündmuseni - kui enesestmõistetavat ajaloo jätkuvust.

Selle strateegia ilmnemine Karjala historiolades ja eriti sünnisõnades võib olla üldisemalt seotud ootustega, mis taasloovad koherentse põhjusliku ajaloo alates haigustekitaja müütilisest sünnist kuni tervendamisriituseni, ja selle edukaks tulemiks on sidus narratiivne järgnevus. Kuigi need erinevad historiolad on narratiivse väe järjepidevuse viljad - mis mõnel juhul võivad ulatuda tuhandete aastate taha - rõhutab see, et järjepidevust tuleb seostada ülekandmise reaalsusega, mille käigus need ka kindlasti radikaalselt muutusid.

\section{Tietäjä riitused kui narratiive draama}

Martti Haavio on kirjutanud ulatusliku ülevaate tietäjä riituse esitusest kui draamast: tietäjä on näitemängulise etenduse lavastaja ja peaosatäitja, kusjuures oma vastastegelasi avab ta oma monoloogis, pealtnäha lihtsa süžeekavandi järgi, kus “tietäjä relvastab end, kogub toetajaid, osaleb tulises lahingus, saab võitu oma vaenlaste üle ja saadab nad vangi." ${ }^{20}$ Puudub šamaaniriitustele iseloomulik ohtliku teekonna narratiiv teispoolsusesse minemisest ja tagasitulemisest. Tegevuses domineerib täielikult tietäjä ego, ta on lava keskmes ja tal on ainsana rääkiv roll. Kuigi tervendamisriitus avab interaktsioonikanalid nähtamatu maailmaga, ei ole ükski vastasroll mitte kunagi seotud kõnega - isegi piksejumal Ukko, kes vastab palvetele ja pakub tuge, kaitset või relvi, aktualiseerub vaid tietäja kirjelduste või kõneaktide kaudu, mitte ise kõneldes. Tietäjä võib aktualiseerida kaugeid paiku teises ilmas ja selle elanikke, neilt midagi paluda või neid käskida, kuid reageeringud ei ole kunagi verbaalsed. Otsene kõne on võimalik ainult historiolade kontekstis.

\section{Vastastikune suhtlus}

Tietäjä aktualiseerib oma rolli ekstaatilise teispoolsuse vahendajana ja avab vahetu suhtluskanali nähtamatu maailmaga. Siikala (2002a: 245) rõhutab, et riitus oli protsess, milles esituse verbaalsed aspektid (näiteks abi palumine 
surnutelt, müütilistelt olenditelt ja hingeaitajatelt, ja rütmiline loitsimine) aitasid tietäjäl liikuda kogemusliku maailma reaalsusest "omaenda siseilma": "loitsude abil tekitati müütiline maailm, kuhu oli juurdepääs vaid tietäjäl.” Tietäjä strateegiad on sarnased nendega, mida kasutab šamaan, kui ta liigub elavast maailmast internaliseeritud narratiivsesse maailma.

Loitsimine on riituse-etendusest arusaamise võtmeks - narratiivide, seletuste, nähtamatu maailma elanike kõnetamise ja kirjelduste kaudu. Verbalisatsioon aktiveerib ja aktualiseerib vastandrolle, kohti, jõudusid ja objekte nähtamatus maailmas, ning need on interaktsioonis etenduses kasutatavate visuaalsete motiivide ja tegevustega, väljendades kas kaudselt või otseselt oma olulisust (see Frog 2009a). ${ }^{21}$ Kuid tietäjä reaalsusorientatsioon liigub narratiivide maailma konkreetse poeetilise süsteemi kaudu, mis vahendab nähtamatu maailma aktiveerimist ja manipuleerimist etenduses.

Loitsudel ei ole alati (eksplitsiitselt) selge ja loogiline süžeeline struktuur (Siikala 1986; 2002a: 100-104), ning verbaalsed, visuaalsed ja narratiivsed üksused ei pruugi olla omavahel seotud. Kujundite ja narratiivsete motiivikomplekside relevantsus või nende omavahelised suhted ei ole selgelt väljendunud ja tulevad esile pigem ootuste struktuurides, sageli muutub sõnum arusaadavaks sellele eelnevate ja järgnevate väidete kontekstis. Riitus ja loits kui selle verbaalne väljendus omandavad semantilise koherentsuse segmentide seeriana, mis tekitavad terviku. Siikala (2002a: 99) kirjeldab seda nii: “olenemata sellest, milline on [loitsutekstide] komplekssus ja varieeruvus, on nad struktureeritud kui motiivide ja klišeede tähenduslik tulem":

Motiivide lineaarne järjestus peegeldab tervendamisriituse süžeestruktuuri. Tegu ei ole vaid kontiinumi-taolise sündmuste seeriaga, vaid hierarhilise struktuuriga, kus peasündmused ja tegevused, mis põhisündmustele loogiliselt järgnevad või neid võimaldavad, järgnevad üksteisele ajalises järjestuses. [---] Riituse käigus selguvad motiivide vahelised näiliselt vastastikku sõltuvad seosed. Tervendamisriituse süžee kohaselt on [loitsuteksti] skeem hierarhiline. (Siikala 2002a: 104.)

Järgides pärimuslikke piiranguid ja tavasid, valib ja korraldab tietäjä oma loitsudes asjakohaseid elemente, moodustades narratiivi kui kogemuse. Elementide selektsioon ja nende aktiveerimine nähtamatus maailmas, nende verbaalsesse fookusesse tõmbamine näib olevat otseselt seotud transsi minemisega teispoolsuse 'visualiseerimisega'. Selle protsessiga ehitab tietäjä ka teatud mõttes enda ja oma riituse-etenduse ümber nähtamatut maailma ning aktualiseerib neid paiku, tunnuseid ja olendeid, kes/mis on konkreetseks etenduseks olulised. Riituse-etendust saab kirjeldada kui emergentset/ilmnevat narratiivi, kuna rituaalispetsialisti kasutatavad strateegiad on ette kirjutatud ja efek- 
tiivsed ning eeldavad reageeringuid ja tagajärgi nähtamatus maailmas, samas kui narratiiv ise ei ole narratiivne üksus objektiivselt äratuntava identiteediga nagu müüt või historiola: narratiiv tekib kui unikaalne kontekstispetsiifiline kogemus.

\section{Tietäjä tervendamisriitused: sild maailmade ja sild erinevate strateegiate vahel}

Tietäjö riituse-etendus avab vastastikuse suhtluse kanali nähtamatu maailma ja selle elanikega. Riitustes kasutatav sõnakunst hõlmab ainult loitse, kuid need sarnanevad rohkem šamaanilauludele kui päheõpitud loitsudele, mis avaldavad mõju nähtamatule maailmale, kuid ei ava suhtluskanaleid nähtamatu maailmaga. Tietäjä riituse abil aktualiseeritakse vastasrolle ja algatatakse interaktsioon. Kuid teatud määral varjutab suhtluses osalevate olendite olulisust tietäjä enda monoloogiline esitus: vastasrollid tegutsevad ja reageerivad, kuid sõnadeta. Riituses kasutatavad mütoloogilised narratiivid annavad tervendamisaktile müütilised proportsioonid, osaledes narratiivis kui koherentne ja piiritletud narratiiv, mis kulmineerub tervisehäda edukas lahenduses. Ootuste struktuurid on raamiks propositsionaalset informatsiooni puudutavate järelduste tegemisel ja projitseerivad etteaimatava interaktsiooni järgnevuse. Kuid see, mis suunab interaktsiooni oodatava tulemuseni, on nendesse struktuuridesse pärimuse tõttu laetud narratiivne vägi. Tietäjä etendus muutub müütilise maailma keskmeks, kaotab võimatud vahemaad teispoolsuse topograafias ning muudab need kirjeldusteks, mis vahetult iseloomustavad sealseid paiku, elanikke ja tegevusi. Oma väelise kõnelemise kaudu näitab tietäjä, et need nähtamatud olendid ja jõud kuulavad tema palveid ja nõudmisi või alluvad tema väele - tegu on šamaaniriitustele sarnaneva skeemiga, kus emergentne narratiiv esitatakse reaalajas nähtamatu, müütilise ja narratiivse maailma kaudu.

Nähtamatu narratiivse maailma vastasrollide tegevust ja reaktsioone on võimalik eeldada ja neid ka vastavalt sundida, kuid süžeekavand ei kirjuta vastandrollidele midagi ette: riituse skript üksnes eeldab nähtamatu maailma mõju ja reageeringuid. Riituse tõhusus sõltub nähtamatu maailma osalemisest, kuid see maailm ei anna oma nõusolekut ettenähtud süžeekavandile enne riituse kui interaktiivse jada algust. Rituaalispetsialist etendab näitemängutaolist etendust, kus ta aktualiseerib tervendaja rolli rituaalispetsialisti ja nähtamatu maailma ekstaatilise vahendajana. Ta näeb etenduses ette ja suhtleb paljude vastasrollidega, mis võivad olla soosivad ja toetavad jõud, kuid ka vaenulikud, võistlevad ja vastuhakkavad. Süžeekavand näeb ette etteaimatavaid interaktsioonimustreid ja funktsioone kui narratiivse väe rakendamist, mis 
õhutab ja/või sunnib vastandrolle reageerima ja osalistena asjakohaselt vastastikku toimima müütiliste proportsioonidega sotsiaalses interaktsioonis. Riituse süžeekavand on struktureeritud narratiivne raamistik, mis loob emergentse narratiivse kogemuse, sest seda mitte ainult ei etendata, vaid see peab ka ette nägema ja säilitama interaktsiooni nähtamatu maailmaga nii, et isegi kui vastav soov tekib, ei kaldutaks kõrvale põhisüžeest.

\section{Kultuurikeskkond ja kultuuri strateegia}

Kõigis neis erinevates traditsioonides on riituse-etendus praktiline ja mõistlik strateegia terviseprobleemi lahendamiseks narratiivse väe (ja näiteks sõna jõu) abil konkreetses kultuurikeskkonnas. Pärimuse sees areneb narratiivne vägi vastavalt selle kultuurilisele kasutusele. Tietäjä traditsioon näib pärinevat neist pärimustest, mis tekkisid Euroopa loitsutraditsioonis šamanistliku pärimusega segunedes. Šamanistlik kultuurikiht näib olevat säilinud kristalliseerunud keelelistes väljendites ja motiivides, millega loitsudes manipuleeritakse (Siikala 2002a). Tietäjä-traditsiooni paljud tunnusjooned ja narratiivsed mustrid võivad küll pärineda šamanistlikust kultuurikeskkonnast, kuid A.-L. Siikala (2002a: 335-349) toonitab, et selle eepiline materjal paneb väiksemat rõhku teispoolsusele kui sealt saadud loitsudele või teadmisele - millest saab tietäjä internaliseeritud atribuut ja mis kaotab vajaduse teha hingerännak (vrd Siikala 2002c). Seoses tietäjäinstitutsiooni arenguga näib eepiline traditsioon olevat olulisel määral muutunud (Siikala 2002a; vrd Reynolds 1995: 207-212). See on otseses seoses sellega, et tietäjä on eepilise žanri puhul mõjuvõimu kanal. On tõenäoline, et tietäjäinstitutsioon, avaldades mõju eepilisusele, võib olla vastavalt kujundanud ka kujutluspilti haigusest.

Karjalas on haigusseletus kujunenud arusaama kohaselt, et võorrelemendid või teiste olenditega seostatavad välised jõud tungivad mingisse konkreetsesse kohta kehas, või kleepuvad välised elemendid keha külge: "kehaline korrastamatus ja haigus arvati pärinevat väljastpoolt keha, mitte selle seest" (Stark 2006: 158). Lisaks hingekaotusele, s.t vitaalse elemendi või jõu kadumisele kehast, mis tuleb tagasi saada või asendada, säilis šamanistlikes kultuurides ka arusaam kehasse tunginud haigustekitajatest, mida raviti kurjade vaimude väljaajamisega, mis on võrreldavad tietäjä omadega (Bäckman \& Hultkrantz 1978: 15-16; Siikala 2002a: 92). Hingekaotus on väga levinud ja stereotüüpne haigusseletus (Honko 1959: 27-29; 1960: 67-71; Siikala 2002a: 85). Kuid L. Honko (1960: 71-72) osundab, et hingkaotusega assotsieeruv motiivistik küll peegeldub Soome-Karjala folkloori narratiivses žanris, kuid seda ei kasutata haiguste seletamisel. L. Honko (1959: 127-129; 1960: 67-71) on tähelda- 
nud seost hingekaotuse kui seletava haiguspõhjuse ja kultuurikeskkonna vahel, kus on säilinud šamanismiga seonduvad ekstaatilised tehnikad. Seega on tõenäoline, et hüpoteetilises Soome-Karjala tüüpi šamanismis, millega seoses on tekkinud ka tietäjä institutsioon, oli hingekaotuse fenomen haiguste diagnoosimisel teada, kuid see kadus käibelt haigusseletusena või oli teadlikult tõrjutud tietäjä kui institutsiooni poolt.

Kriisi lahendamiseks kasutatavad strateegiad sõltuvad haiguse kontseptsioonist, ja tietäjä mitte ainult ei ravinud, vaid ka diagnoosis. Haiguste diagnoosimise strateegiad tuginesid loomulikult assotsiatsioonidele ja ootustele. Haiguste diagnoosimisel võis tietäjä eelistada teatud seletavaid kontseptsioone (Siikala 2002a: 85). Karjala tervendamisriitustes kasutatavad strateegiad ja asjaolu, et diagnoosimistraditsioonis puudus hingekaotus, näivad olevat otseses seoses. Riituste käigus tõrjuti haigustekitaja patsiendi kehast välja, kasutades strateegiat, mis takistas sellel kehasse tagasi pöördumast, kuid puudusid strateegiad, kuidas saada jagu nähtamatu maailma objektidest või elementidest, mida võidi tahta maha suruda (näit hingerännak allutamaks mingit kauget müütilist jõudu).

Saami šamanismis oli hingekaotus haiguste diagnoosimisel väga oluline põhjus (Bäckman \& Hultkrantz 1978: 44). Soome-karjalased on sajandite vältel olnud tihedas kontaktis saamidega (vt nt Pöllä 1995; 1999). Tietäjä traditsioonis väärtustatakse väga saamidelt saadud maagilise teadmuse väärtust ja mõjuvõimu (Haavio 1967: 326; Siikala 2002b: 34; Tarkka 2005: 127), seega ei saa väheseid kontakte pidada põhjuseks, et tietäjä ei arvestanud diagnoosimisel hingekaotust kui võimalikku haiguspõhjust. Samas näib, et tietäjäl puudusid asjakohased strateegiad sellise haiguskriisi lahendamiseks, ka näib tietäjä üldiselt eiravat või aktiivselt eitavat tõika, et kehast eemaldunud hing võib olla oluline haiguspõhjus, või et seda tuleks ravida. Seda nimetab L. Honko (1981: 24-25) "traditsiooni tsensuuriks", kuid seda tsensuuri tuleb mõista kui ajaloolist sättumust, mis tekkis järjepideval suhtlemisel saamidega. Hingekaotus või hingevargus on motiivid, mis assotsieeruvad saamidega, nagu hingerännakki. See on võrreldav näiteks nende suhteliselt harvade juhtudega, kui tietäjä kasutab maagilises etenduses trummi - trummi kasutamine on selgelt üle võetud saamidelt (Siikala 1991: 202-203; Siikala 2002: 278) - ja kirjeldustega, kus tietäjä läheb teadvusetusse transsi ning kulgeb hingerännakule samamoodi kui saami nõid (Siikala 1991: 202; Siikala 2002: 277). Pidades silmas ajaloolisi suhteid saamidega, saab asjaolu, et tietäjä ei arvestanud hingekaotuse kui ühe võimalusega haiguste diagnoosimisel, osaliselt seletada prioriteetsete tervendamisstrateegiate ja rahvapäraste haiguspõhjustega. Ajaloolised kontaktid maagilistes praktikates ja vastavad mõjutused tähendavad seda, et traditsioon tsenseeris ka nende motiivide narratiivse väe järjepidevust, seostades neid 'teisega'. ${ }^{22}$ 


\section{Kokkuvõte}

Kõigi siinkäsitletud traditsioonide puhul on tegu narratiivse väe järjepidevusega - teatud strateegiad säilitasid oma väärtuse ja olulisuse ressurssidena, mida sai kasutada ja manipuleerida maagilise toime eesmärgil. Euroopa loitsutraditsioon kasutab fikseeritud tekste, millel võib olla järjepidevus kasutusstrateegiates, kuid kontinuiteet riituse esituse ja tervendamissündmuse vahel on ebaselge ja võimaldab erinevaid tõlgendusi, samas ei ole pärimuse puhul nõutav, et sellest 'aru saadakse'. Šamanistlik traditsioon on hämmastavalt mitmekesine, kuid samas on tegu ka äärmiselt subjektiivse internaliseeritud arusaamisega müütilisest maailmast ja narratiivse väe manipuleerimisstrateegiatest, mis on tõhus vahend, saavutamaks patsiendi tervenemist interaktsioonis nähtamatu maailmaga. Tietäjä riitused on kujunenud nende kahe strateegia vahepeal. Kasutatud meetrika soosib üksikute värsiridade kristalliseerumist, samal ajal luuakse värsiridadest paindlikumaid kogumeid, mis on tuttavlikud kompositsioonilised üksused loitsudes ja muudes žanrites. See, mil määral oli riituse-etendus muutuv emergentne narratiiv ja seega sarnasem šamaaniriitusele, või järjekindlalt taasloodud - ja verbaalselt paindlik - narratiiv, mis on lähedane pigem Euroopa loitsutraditsiooni strateegiatele sõltus konkreetsest tietäjäst, isegi kui kultuurikeskkond pidas oluliseks nähtamatust maailmast arusaamist ja loitsuelementide kasutamist: ilmselgelt saadi narratiivsest väest aru ja seda kasutati erinevalt, samamoodi oli varieeruv see, kuidas narratiivset väge tõlgendati, kas sõna-sõnalt, abstraktselt või metafooriliselt (vrd Piela 2006).

Kõnealuseid traditsioone on artiklis käsitletud üldistatult, et anda ülevaade kasutatud strateegiatest ja näidata, kuidas need strateegiad mõjutavad ja on koostoimes teiste nähtustega pärimusökoloogias, nähtustega, mis sajandite vältel võisid kujundada paljusid traditsioone ja üldisemalt ka maailmapildi eri aspekte. Kuid tuleb meeles pidada, et need traditsioonid on alati olnud pigem dünaamilised kui ühetaolised, ja just paindliku ja avatud tõlgendamise tõttu on nende traditsioonide narratiivne vägi suutnud jääda ajas ja muutuvas kultuuris püsima elutähtsa meetodina kriiside lahendamisel.

\section{Tõlkinud Mall Leman}

\section{Kommentaarid}

${ }^{1}$ Eelistan terminit 'riitus', ja et pärimus on väga variatiivne, on asjakohane käsitleda etendust kui 'riitusetehnika' rakendamist riituse etendamisel; termin 'rituaal' eeldab palju suuremat järjepidevust kui mingis piirkonnas olla saab. Enamik 'rituaali'-käsitlusi on orienteeritud sotsiaalsete süsteemide ja võimusuhete säilitamisele, 
mille asjakohasus tuleb täielikult esile alles tietäjä tervendamisriitustes, kui nähtamatu maailma elanikud kaasatakse oluliste liikmetena säilitatavatesse süsteemidesse.

2 Ulla Piela (2005: 13) tsiteerib Matti Hako 1956. aasta väitekirja kui varaseimat näidet näitemängu-analoogiast.

3 Tsur esitab selle väite oma määratluses, kus ta vastandab vaimse etenduse (mental performance) vokaalsele etendusele (vocal performance), mis on orienteeritud kindla teksti lugemisele ja retsiteerimisele, kuid seda saab kasutada ka suulise pärimuse puhul, kus variaablus on palju suurem. Lugemaks käsitlust eepika võimest laieneda, kokku tõmbuda ja olla jagatud etendatud osadeks vt Honko 1998: 30-36.

4 Lugemaks huvitavat näidet ja vastavat arutelu vt Kaivola-Bregenhøj 1996: 138157; vrd Lehtipuro 1992: 173.

5 Edu on muidugi vaataja silmades. Näidet selle kohta, kuidas etendus jäi lõpetamata vaatajate huvipuuduse tõttu vt Dégh 1995: 94-95; vrd Başgöz 1975.

6 See kirjeldus on laenatud Pentti Määttänenilt (1993).

7 "Kui me arvestaksime surma kontseptsiooni ennetes, itkudes, uskumusmuistendites, vanasõnades, lugudes, ballaadides jne, oleks meil varsti sama palju surma mõisteid kui vastavaid žanre" (Honko 1981: 26).

${ }^{8}$ Klein mainib eriti Märcheneid (vrd Dégh 1995), kuid sedasama võib öelda ka eepika kohta (Reynolds 1995; Tarkka 2005: 160-198).

${ }^{9}$ Oleks mõistlik arvata, et mida vähem piiravam ja stiliseeritum on diskursuses väljendatav strateegia, seda täpsemalt peegeldab selle representatsioon neid elemente, mida indiviid peab selle diskursuse kontekstis kogemuslikult oluliseks s.t, et diskursus peaks andma aimu sellest, kuidas filtreerida semiootiliselt olulisi elemente ('ta hakkas higistama' = 'ta oli närvis') semiootiliselt mitteolulistest ('iga poor ta ninal oli selgelt näha'), seda just unikaalse personaalse kogemuse tõlgendamise tasandil.

${ }^{10}$ Olen käsitlenud kujundi jõudu ja selle rakendamist koos sõna jõuga, tuues näiteid tietäjä riituse-etendusest mujal (Frog 2009a).

${ }^{11} \mathrm{D}$. Frankfurter kasutas terminit jutustamise vägi ('narrating power'); ta keskendus üksnes maagilise müütilise olulisuse säilitamisele ega käsitlenud retoorilisi või esteetilisi funktsioone. Tekitamaks selgema seose mõistetega sõna jõud ja kujundi jõud, eelistatakse siinkohal kasutada terminit narratiivne vägi ('narrative power'), mitte Frankfurteri jutustamise väge.

${ }^{12}$ Sageli toimib narratiivne vägi vaevu hoomataval või isegi alateadvuslikul tasandil. Esituse kaudu aktiveeritud vägi ja jõud on kõige ilmsemad siis, kui neid manipuleeritakse retoorilise ja esteetilise mõju saamiseks, ja suhestutakse tavadega, mitte ei järgita neid, või kui need rakendamisel 'ei toimi' (vrd Tsur 1992a:10-12).

${ }^{13}$ Seda juhtub sageli siis, kui narratiivsete elementide indeksiaalsed assotsiatsioonid on loitsimise kontekstis suutelised aktiveerima sotsiaalselt äratuntavat tekstilist või tekstivälist narratiiviüksust. Kuigi see on tegelikult ootusi ja propositsionaalset informatsiooni puudutav funktsioon, toimib siin samavõrra ka narratiivne vägi, mis annab aktivatsioonile kaalu, jõudu ja ulatust - seda kandva pärimuse impulssi. Alates metonüümilisest aktiveerimisest saab öelda, et terviku narratiivne vägi on aktiveeritud, kandmaks maagilise jõu mitte-propositsionaalset tähendust. Selline arusaam on subjektiivne ja intuitiivne, ja historiolaga manipuleerija ei pruugi 
mõista, et metonüüm assotsieerub suurema tervikuga või et see võib seostada sinna inkorporeeritud elemendid narratiivse väega (või kujundi jõuga, kui tegu on vaid kujundiga või sõna jõuga, kui tegu pole enamaga kui voces magicae).

14 Tekstiüksus on sotsiaalselt tunnustatud narratiiv, nt "Loomise laul", mis taasluuakse vastavalt mingitele üldistele strateegiatele; tekstiväline üksus on sotsiaalselt tunnustatud narratiiv, mis on tavapäraselt internaliseeritud vastavalt erinevatele dünaamilistele kultuurilistele väljenduslaadidele, näit Jeesuse elu ja surma puudutavad narratiivid tänapäeva kultuuris, mis keskenduvad piibli kaudu edastatud narratiivsetele tekstiüksustele, kuid neid internaliseeritakse peamiselt nende laiema kultuurilise tegevuse kaudu.

${ }^{15}$ Siin esitatud diskussioon keskendub Euroopa ja Aasia šamanistlikule traditsioonile. Käesoleva arutelu puhul piisab nende üldisest käsitlusest, kuna tehtud märkused on peamiselt tüpoloogilised. Kõnealuste traditsioonide olulisus seisneb nende ajaloolistes kihistustes tietäjä-traditsioonis, mis on "üle võtnud rolli, mida šamaan mängis iidsetes kogukondades", kes "säilitasid šamanistliku mõttemudeli" (Siikala 2002a: 42). Kuid seda saab siiski käsitleda vaid üldiselt, sest ülestähendatud šamanistlik pärimus Põhja-Euroopa ja Aasia kultuurides on olnud järjepidevalt arenev protsess, sama kaua kui tietäjä institutsioonigi: ükski kirjapandud šamanismi ilming ei anna põhjust väita, et tietäjä institutsioon tekkis või arenes Soome-Karjala muistse šamaani-institutsiooni kaudu või sellega seoses.

${ }^{16}$ Rolliteooria kohta vt Biddle 1979.

${ }^{17}$ Esteetiliselt markeeritud üldise kommunikatsiooni kohta vt Bauman \& Briggs 1990: 73; semiootilise olulisuse muutumine kui rituaali karakteristik vt Bell 1992.

18 See on veel üks valdkond, milles tietäjä-institutsioon on võrreldav šamaaniga: vrd Hoppál 1998: 127-129; Reichl 2000: 19-20, 36-37; vt ka Harvilahti 2003: 90-115.

19 Frog 2008; 2009a. Vana ülemsaksakeelne 2. Merseburgi loits on näide historiolast, mis esindab narratiivse väe dokumenteeritud järjepidevust (ja muutumist) umbes tuhande aasta jooksul (Christiansen 1914), sellele lisatud tervendamissõnad võivad olla pärit veel mitme tuhande aasta tagusest ajast (Watkins 1995: 519-536).

${ }^{20}$ Haavio 1967: 340; kogu lõigu ingliskeelset tõlget vt Siikala 2002a: 100.

${ }^{21}$ Sõnakasutus tegevuste või nende olulisuse defineerimisel või ümberdefineerimisel on paljude erinevate maagiliste etenduste üldine tunnus (vrd Kõiva 1996: 60-64).

${ }^{22}$ See on seostatav Clive Tolley (2009) hiljutiste järeldustega, mis puudutavad keskaegsete germaani ja saami maagiatavade suhteid.

\section{Kirjandus}

Alexander, Alex E. 1973. Bylina and Fairy Tale: the Origins of Russian Heroic Poetry. The Hague: Mouton.

Aronsson, Karin 2001. Narrative, Sociology of. Smelser, Neil J. \& Baltes, Paul B. (toim). International Encyclopedia of the Social \& Behavioral Sciences. Oxford: Pergamon, lk 10284-10289.

Bäckman, Louise, \& Åke Hultkrantz 1978. Studies in Lapp Shamanism. Stockholm Studies in Comparative Religion 16. Stockholm: Almqvist \& Wiksell International. 
Başgöz, Ílhan 1975. The Tale-Singer and His Audience: An Experiment to Determine the Effect of Different Audiences on a Hikaye Performance. Ben-Amos, Dan \& Goldstein, Kenneth (toim). Folklore: Performance and Communication. The Hague: Mouton, lk 142-203.

Bauman, Richard, \& Charles L. Briggs 1990. Poetics and Performance as Critical Perspectives on Language and Social Life. Annual Review of Anthropology 19, lk 59-88.

Bell, Catherine 1992. Ritual Theory, Ritual Practice. Oxford: Oxford University Press.

Biddle, Bruce J. 1979. Role Theory: Expectations, Identities, and Behaviors. New York: Academic Press.

Briggs, Charles L. \& Mantini-Briggs, Clara 2003. Stories in the Time of Cholera: Racial Profiling during a Medical Nightmare. Berkeley: University of California Press.

Christiansen, Reidar Th. 1914. Die finnischen und nordischen Varianten des zweiten Merseburgerspruches: Eine vergleichende Studie. FF Communications 18. Hamina.

Comparetti, Domenico 1898. The Traditional Poetry of Finns. London: Longmans.

Dégh, Linda 1985. 'When I Was Six We Moved West ... ;' the Theory of Personal Experience Narrative. New York Folklore 11, lk 99-108.

Dégh, Linda 1995. Narratives in Society: A Performer-Centered Study of Narration. FF Communications 255. Helsinki: Suomalainen Tiedeakatemia.

van Dijk, Teun A. 1980. Macrostructures: An Interdisciplinary Study of Global Structures in Discourse, Interaction, and Cognition. Hillsdale: Erlbaum \& Associates.

Eliade, Mircea 1963. Myth and Reality. London: George Allen \& Unwin.

Foley, John Miles 1992. Word-Power, Performance, and Tradition. The Journal of American Folklore 105, lk 275-301.

Foley, John Miles 1995. The Singer of Tales in Performance. Bloomington: Indiana University Press.

Frankfurter, David 1995. Narrating Power: The Theory and Practice of the Magical Historiola in Ritual Spells. Meyer, Marvin \& Mirecki, Paul (toim). Ancient Magic and Ritual Power. Religions of the Graeco-Roman World 129. Leiden: Brill, lk 457-476.

Frog 2008. The 'Blue Stone' in Finnish Healing Rituals and Incantation Formulae Синий камень в финских лечебных ритуалах. Савельева, Галина \& Ильина, Ирина $\&$ Володин, Владимир (toim). Народная медицина в системе культурной адаптации населения Европейского Севера: итоги и перспективы междисциплинарных исследований. Сыктывкар: Изд-во Кола, lk 141-161.

Frog 2009a. Do You See What I See? The Mythic Landscape in the Immediate World. Folklore. Electronic Journal of Folklore. Tartu, 43, lk 7-26.

Frog 2009b. Speech-Acts in Skaldic Verse: Genre, Formula and Improvisation. Dewey, Tonya Kim \& Frog (toim). Versatility in Versification. Multidisciplinary Approaches to Metrics. New York: Peter Lang, lk 223-246.

Haavio, Martti 1967. Suomalainen mytologia. Porvoo: Werner Söderström Osakeyhtiö. 
Harvilahti, Lauri 2003. The Holy Mountain. FF Communications 282. Helsinki: Academia Scientiarum Fennica.

Hästesko, F. A. 1918. Länsisuomalainen loitsurunous. Helsinki: Suomalaisen Kirjallisuuden Seura.

Hatto, Arthur 1970. Shamanism and Epic Poetry in Nortern Asia. Foundation Day Lecture 1970. London: School of Oriental and African Studies, University of London.

Honko, Lauri 1959. Krankheitsprojektile: Untersuchung über eine urtümliche Krankheitserklärung. FF Communications 178. Helsinki: Suomalainen Tiedeakatemia.

Honko, Lauri 1960. Varhaiskantaiset taudinselitykset ja parantamisnöytelmä. Hautala, Jouko (toim). Jumin keko: tutkielmia kansanrunoustieteen alalta. Helsinki: Suomaliasen Kirjallisuuden Seura, lk 41-111.

Honko, Lauri 1972. Uskontotieteen näkökulmia. Taskutieto 85. Porvoo: WSOY.

Honko, Lauri 1981. Four Forms of Adaptation of Tradition. Honko, Lauri \& Voigt, Vilmos (toim). Adaptation, Change, and Decline in Oral Literature. Studia Fennica 26. Helsinki: Suomalaisen Kirjallisuuden Seura, lk 19-33.

Honko, Lauri 2000. Thick Corpus and Organic Variation. An Introduction. Honko, Lauri toim). Thick Corpus, Organic Variation and Textuality in Oral Tradition. Studia Fennica Folkloristica 7. Helsinki: Finnish Literature Society, lk 3-28.

Honko, Lauri 2003. The Maiden's Death Song and The Great Wedding:Anne Vabarna's Oral Twin Epic Written down by A. O. Väisnen. FF Communications 281. Helsinki: Suomalainen Tiedeakatemia.

Hoppál, Mihály 1998. Shamanism: An Archaic and/or Recent System of Beliefs. Siikala, Anna-Leena \& Hoppál, Mihály (toim). Studies on Shamanism. Ethnologica Uralica 2. Helsinki: Finnish Anthropological Society, lk 117-131. [Esmatrükk 1985. Ural-Altic Yearbook 57, lk 121-140.]

Hymes, Dell 1975. Folklore's Nature and the Sun's Myth. The Journal of American Folklore 88, lk 345-369.

Hymes, Dell 1986. Models of the Interaction of Language and Social Life. Gumperz, John J. \& Hymes, Dell (toim). Directions in Sociolinguistics: The Ethnography of Communication. Oxford: Blackwell, lk 35-71.

Johnson, Mark 1987. The Body in the Mind. The Bodily Basis of Meaning, Imagination, and Reason. Chicago: University of Chicago Press.

Kaivola-Bregenhøj Annikki 1996. Narrative and Narrating: Variation in Juho Oksanen's Storytelling. FF Communications 261. Helsinki: Academia Scientiarum Fennica.

Klein, Barbro 2006. Introduction. Kaivola-Bregenhøj, Annikki \& Klein, Barbo \& Palmenfelt, Ulf (toim). Narrating, Doing, Experiencing: Nordic Folkloristic Perspectives. Studia Fennica Folkloristica 16. Helsinki: Finnish Literature Society, lk 6-28.

Krohn, Kaarle 1924. Magische Ursprungsrunen der Finnen. Bussenius, Arno (tlk). FF Communications 52. Helsinki: Academia Scientiarum Fennica.

Kõiva, Mare 1996. The Transmission of Knowledge Among Estonian Witch Doctors. Folklore. Electronic Journal of Folklore 2, lk 41-72. 
Lakoff, George, \& Johnson, Mark 1980. Metaphors We Live by. Chicago: University of Chicago Press.

Lifton, Robert J. 1961. Thought Reform and the Psychology of Totalism. New York: Norton.

Lönnroth, Lars 1978. Den dubbla Scenen: Muntlig Diktning från Eddan till ABBA. Stockolm: Prisma.

Lotman, Yuri M. 1990. Universe of the Mind:A Semiotic Theory of Culture. Bloomington: Indiana University Press.

Määttänen, Pentti 1993. Action and Experience. A Naturalistic Approach to Cognition. Helsinki: Suomalianen tiedeakatemia.

Olsan, Lea 1992. Latin Charms of Medieval England: Verbal Healin in a Christian Oral Tradition. Oral Tradition 7, lk 116-142.

Peirce, Charles Santiago Sanders 1940. Logic as Semiotic: The Theory of Signs. Buchler, Justus (toim). The Philosophy of Pierce: Selected Writings. New York: Routledge \& Kegan Paul, lk 98-119.

Piela, Ulla 2005. Parantajan rituaalinen kosketus. Huttunen, Sirpa \& Nuolijärvi, Pirkko (toim). Tahdon sanoa. Kirjoituksia kielen ja perinteen voimasta. Helsinki: Suomalaisen Kirjallisuuden Seura, lk 11-31.

Piela, Ulla 2006. Luonto ja muuttuvat maailmat kansanlääkinnässä. Helsti, Hilkka \& Stark, Laura \& Tuomala, Saara (toim). Modernisaatio ja kansan kokemus Suomessa 1860-1960. Helsinki: Suomalaisen Kirjallisuuden Seura, lk 277-331.

Reichl, Karl 2000. Singing the Past: Turkic and Medieval Heroic Poetry. Ithaca: Cornell University Press.

Reynolds, Dwight Fletcher 1995. Heroic Poets, Poetic Heroes. The Ethnography of Performance in an Arabic Oral Epic Tradition. Ithaca: Cornell University Press.

Roper, Jonathan 2006. English Verbal Charms. FF Communications 288. Helsinki: Finnish Literature Society.

Ross, Robert N. 1975. Ellipsis and the Structure of Expectation. San Jose State Occasional Papers in Linguistics 1.

Sarbin, Theodore 1954. Role Theory. Lindzey, Gardner \& Aronson, Elliot (toim). Handbook of Social Psychology I: Theory and Method. Cambridge: Addison Wesley, lk 223258.

Siikala, Anna-Leena 1978. The Rite Technique of the Siberian Shaman. FF Communications 220. Helsinki: Academia Scientiarum Fennica.

Siikala, Anna-Leena 1986. Variation in the Incantation and Mythical Thinking. The Scope of Comparative Research. Journal of Folklore Research 23, lk 187-204.

Siikala, Anna-Leena 1998. Shamanic Knowledge and Mythical Images. Siikala, AnnaLeena \& Hoppál, Mihály (toim). Studies in Shamanism. Ethnologica Uralica 2. Helsinki: Finnish Anthropological Society, lk 87-106. 
Siikala, Anna-Leena 1991. Singing of Incantations in Nordic Tradition. Ahlbäck, Tore (toim). Old Norse and Finnish Religions and Cultic Place-Names Scripta Instituti Donneriani Aboensis 13. Åbo: Almqvist \& Wiksell Internat, lk 191-205.

Siikala, Anna-Leena 1992. Suomalainen šamanismi. Mielikuvien historiaa. Helsinki: Suomalaisen Kirjallisuuden Seura.

Siikala, Anna-Leena 2002a. Mythic Images and Shamanism. A Perspective on Kalevala Poetry. FF Communications 280. Helsinki: Suomalainen Tiedeakatemia.

Siikala, Anna-Leena 2002b. The Singer Ideal and the Enrichment of Poetic Culture. Why Did the Ingredients for the Kalevala Come from Viena Karelia?. Honko, Lauri (toim). The Kalevala and the World's Traditional Epics. Studia Fennica Folkloristica 12. Helsinki: Finnish Literature Society, lk 26-43.

Siikala, Anna-Leena \& Hoppál, Mihály 1998. Studies in Shamanism. Ethnologica Uralica 2. Helsinki: Finnish Anthropological Society.

SKVR = Suomen kansan vanhat runot I-XV 1908-1997. Helsinki: Suomalaisen Kirjallisuuden Seura.

Stahl, Sandra K. D. 1977. The Personal Narrative as Folklore. Journal of the Folklore Institute 14, lk 9-30.

Stark, Laura 2002. Peasants, Pilgrims, and Sacred Promises. Ritual and the Supernatural in Orthodox Karelian Folk Religion. Studia Fennica Folkloristica 11. Helsinki: Finnish Literature Society.

Stark, Laura 2006. The Magical Self: Body, Society and the Supernatural in Early Modern Rural Finland. FF Communications 290. Helsinki:Academia Scientiarum Fennica.

Suojanen, Päivikki 1993. The Ethnography of Speaking and Religious Communication. A Case Study of Spontaneous Sermon in Finland. Pertti J. Anttonen \& Kvideland, Reimund (toim). Nordic Frontiers. NIF Publications 27. Turku: Nordic Institute of Folklore.

Tarkka, Lotte 2005. Rajarahvaan laulu. Tutkimus Vuokkiniemen kalevalamittaisesta runokulttuurista 1821-1921. Helsinki: Suomalaisen Kirjallisuuden Seura.

Tolley, Clive 2009. Shamanism in Norse Myth and Magic 1. FF Communications 296.

Tsur, Reuven 1992a. Toward a Theory of Cognitive Poetics. Amsterdam: North-Holland.

Tsur, Reuven 1992b. What Makes Sound Patterns Expressive? The Poetic Mode of Speech Perception. Durham: Duke University Press.

Versnel, Henk S. 2002. The Poetics of the Magical Charm: An Essay on the Power of Words. Mirecki, Paul \& Meyer, Marvin (toim). Magic and Ritual in the Ancient World. Religions in the Graeco-Roman World 141. Leiden: Brill, lk 105-158.

Watkins, Calvert 1995. How to Kill a Dragon. Aspects of Indo-European Poetics. Oxford: Oxford University Press. 


\section{Summary}

\section{Narrative as the Cure: Rite Performance and the Actualization of Narrative as Experience}

\section{Frog}

Key words: healing rite, incantation ritual, non-propositional import, performance, shaman, tietäjä

This paper addresses theoretical issues of narrative in an attempt to approach the semantics of understanding underlying the performance of certain healing rites. The first section of the paper introduces the term narrative power to refer to the cultural load developed by narratives and narrative strategies and develops a framework for approaching healing rite performance as the application of strategies which actualize narrative as experience. The Finno-Karelian tietäjä tradition is discussed in relation to shamanic rite performance and memorized traditions of incantations, particularly those which incorporate historiolae.

The European incantation tradition exhibits a fixed text approach which may bear continuities in strategies of application but continuities between performance and the healing event are ambiguous, open to interpretation, and the tradition does not require 'understanding' at all. Shamanic traditions are incredibly diverse, but they present an opposite extreme of subjective, internalized understandings of the mythic world and strategies for manipulating narrative power as an effective means of negotiating the recovery of a patient in interaction with the unseen world. The rites of the tietäjä have evolved between these two sets of strategies. The poetic meter inclines individual lines of verse to crystallize and somewhat flexible constellations of lines emerge as familiar compositional units in incantations and other genres. The degree to which rite performance was a variable emergent narrative nearer shamanic rites or a consistently reproduced - if verbally flexible - narrative more akin to the strategies of the European incantation would be dependent on the individual tietäjä, even if in the cultural milieu emphasis was placed on understanding the unseen world and the significance of elements manipulated in the incantations.

These traditions have been addressed here in generalizations in order to offer an overview of strategies applied and also how those strategies both interact with and affect other phenomena in the tradition ecology which for centuries may have been shaping a remarkable range of traditions and aspects of the worldview more generally. However, it must be remembered that these traditions have always been dynamic rather than uniform, and it is through the flexibility and openness to reinterpretation that the narrative power of these traditions could persist as viable instruments for crisis resolution through centuries of cultural change. 